\title{
Life Cycle Assessment of Apparel Consumption in Australia
}

\author{
Shadia MOAZZEM ${ }^{1}$, Enda CROSSIN ${ }^{2}$, Fugen DAVER ${ }^{3}$, Lijing WANG ${ }^{4 *}$ \\ ${ }^{1,4}$ School of Fashion and Textiles, RMIT University, 25 Dawson St, Melbourne, Victoria 3056, Australia \\ ${ }^{2}$ University of Canterbury, Kirkwood Avenue, Upper Riccarton, Christchurch 8041, New Zealand \\ ${ }^{3}$ School of Engineering, RMIT University, Plenty Road, Bundoora, Victoria 3083, Australia
}

\begin{abstract}
This study presents the environmental impact of apparel consumption in Australia using life cycle assessment methodology according to ISO14040/14044:2006. Available published references, the Ecoinvent v3 dataset, the Australian life cycle assessment dataset and apparel country-wise import data with the breakdown of apparel type and fibre type were used in this study. The environmental impact assessment results of the functional unit were scaled up to the total apparel consumption. The impact results were also normalized on a per-capita/year basis. The Total Climate Change Potential (CCP) impact from apparel consumption of 2015 was estimated to be 16607028 tonnes $\mathrm{CO}_{2} \mathrm{eq}$ and $698.07 \mathrm{~kg} \mathrm{CO} 2 \mathrm{eq} / \mathrm{per}$ capita-year. This study also assessed the impact of acidification potential (AP), water depletion (WD), abiotic resource depletion potential (ADP) - fossil fuel and agricultural land occupation (ALO) using the same methodology. The market volume of cotton apparel in Australia is $53.97 \%$, which accounts for $45 \%, 96 \%, 40 \%, 46 \%$ and $79 \%$ of total CCP, WD, ADP, AP and ALO impact, respectively. Apparel broad categories of cotton shirt, cotton trouser, polyester shirt and polyester trouser have a high volume in the apparel market as well as a high environmental impact contribution. These high-volume apparel products can be included in the prioritization list to reduce environmental impact throughout the apparel supply chain. It was estimated that from 2010 to 2018 the per capita apparel consumption and corresponding impact increased by $24 \%$.
\end{abstract}

Keywords - Apparel consumption; emission per-capita; environmental impact; life cycle assessment

\section{INTRODUCTION}

According to the fashion industry report by Global Fashion Agenda \& the Boston Consulting Group, the global apparel consumption was about 62 million tonne in 2015 [1]. The worldwide apparel consumption continued to rise with population growth and it is expected to rise by $63 \%$, from 62 million tonne to 102 million tonnes by 2030 [1]. The textile and apparel industry is one of the most polluting industries in the world [2], [3]. Textile and apparel products include home textile (bed linens, table linens, curtains, kitchen linens, towels, etc.) and apparel textile (T-shirts, trousers, sweaters, jackets, etc.). The demand for textile and apparel products, and thus textile and apparel production, is increasing. At the same time, the production of the textile products is associated with environmental impacts, including emissions and resource depletion.

\footnotetext{
* Corresponding author.

E-mail address: lijing.wang@rmit.edu.au
} 
There is a growing interest from industry and consumers regarding the environmental impacts and sustainability [4]. Sustainable manufacturing capability of textile companies involves in the supply chain and influences overall business. Different textile companies may have different levels of capabilities in sustainable manufacturing [5], [6]. Environmental sustainability targets can be achieved by encouraging companies to identify their capability gaps and fill those gaps by implementing environmentally sustainable practices [5], [6]. When considering the environmental impacts of textiles, it is important to consider not only production impacts, but also those associated with distribution, use (including product care), and end-of-life [7]. In this respect, the environmental impacts of clothing and textiles should be considered across their entire life cycle.

Most life cycle assessment (LCA) studies on textiles and apparel have typically focused on the production processes for individual textile fibres or competing textile products or fibres [8]-[14]. For example, LCA of wool serves as an ideal methodology to understand the environmental impacts of wool clothing and textiles across their life cycle [15]-[17]. Some studies focused on the environmental performance of clothing and textiles at the end of life [18]-[21]. However, very limited LCA studies focused on the environmental impacts of clothing consumption. A study was undertaken by the European Commission's Joint Research Centre (JRC) on the environmental impact of clothing consumption based on the EU-27 circumstances [22]. An impact analysis of UK clothing was presented by WRAP (Waste \& Resources Action Programme), which focused on only the carbon footprint [23].

Australians demand approximately $27 \mathrm{~kg}$ per person per year for all types of textile and apparel products, which are approximately twice the global average of $13 \mathrm{~kg}$ per capita per year [24], [25]. Therefore, analysing the environmental impacts of textile and apparel consumption in Australia is significant but is largely ignored. This study addresses this research gap by applying an LCA methodology to assess the environmental impact of apparel consumption in Australia. LCA is a tool to assess environmental impacts from the entire life cycle of products or services [26], [27]. Life cycle assessment is widely used to study environmental impact of building materials, waste management, energy sector, supply chain etc., as well as evaluation of sustainability and the circular economy [28]-[30].

In this study, the LCA methodology was used to assess environmental impact of apparel product consumption in order to identify which apparel product categories and fibres have the greatest impact across the apparel life cycle, and which stages and sub-stages in the life cycle have the greatest impact. The impact assessment of consumption perspective helps to demonstrate sustainability policies on apparel products and consumption by prioritization of their environmental impact. It also helps to demonstrate consumer knowledge on apparel consumption. This study focuses on the environmental impacts of apparel products consumed in Australia, except for home textiles. Within that framework, this study presents some results in detail, such as analysing the impact per capita, impact contribution by apparel type, fibre type and the stages involved in the life cycle of apparel. This study uses global trade flows, coupled with production, consumer use and end of life data to quantify the environmental flows. The environmental impacts of these apparel flows are assessed across climate change potential (CCP), acidification potential (AP), water depletion (WD), abiotic resource depletion potential (ADP) and agricultural land occupation (ALO) indicators. The results are then analysed to identify significant contributors (hotspots) of the different impact categories across different product types. 


\section{Methods}

\subsection{Estimation of Apparel Consumption in Australia}

According to the Swedish Environmental Protection Agency, consumption can be defined as the final use of a product or service. Apparel consumption can be estimated according to the report of the European Commission's Joint Research Centre [22] as follows:

$$
\text { Net Consumption = National Production + Imports }- \text { Exports }
$$

In Australia, demand for clothing and apparel is mainly met through imports, which account for about $92 \%$ [31]. To reduce the complexity of the LCA model, only imported apparel quantities were modelled, with impacts scaled to account for the excluded local production. To analyse the total environmental impact of apparel consumption, apparel import quantity breakdown of all apparel categories was collected from the UN Comtrade database. The import quantities with breakdown for all apparel categories for the years 2017 and 2018 are not available in the UN Comtrade database. Therefore, considering the latest availability of the breakdown data of apparel quantity, import quantity for 2015 was used in this study. Market data of the apparel import quantity to Australia for 2015 was collected from the UN Comtrade database under harmonised tariff codes 61 (knit) and 62 (woven) [32]. Fig. 1 presents the apparel import quantity under tariff codes 61 and 62 and values between the years 2008 and 2018 [32]. Apparel import quantity and import value increased about $10.4 \%$ from the 2015 to 2018 .

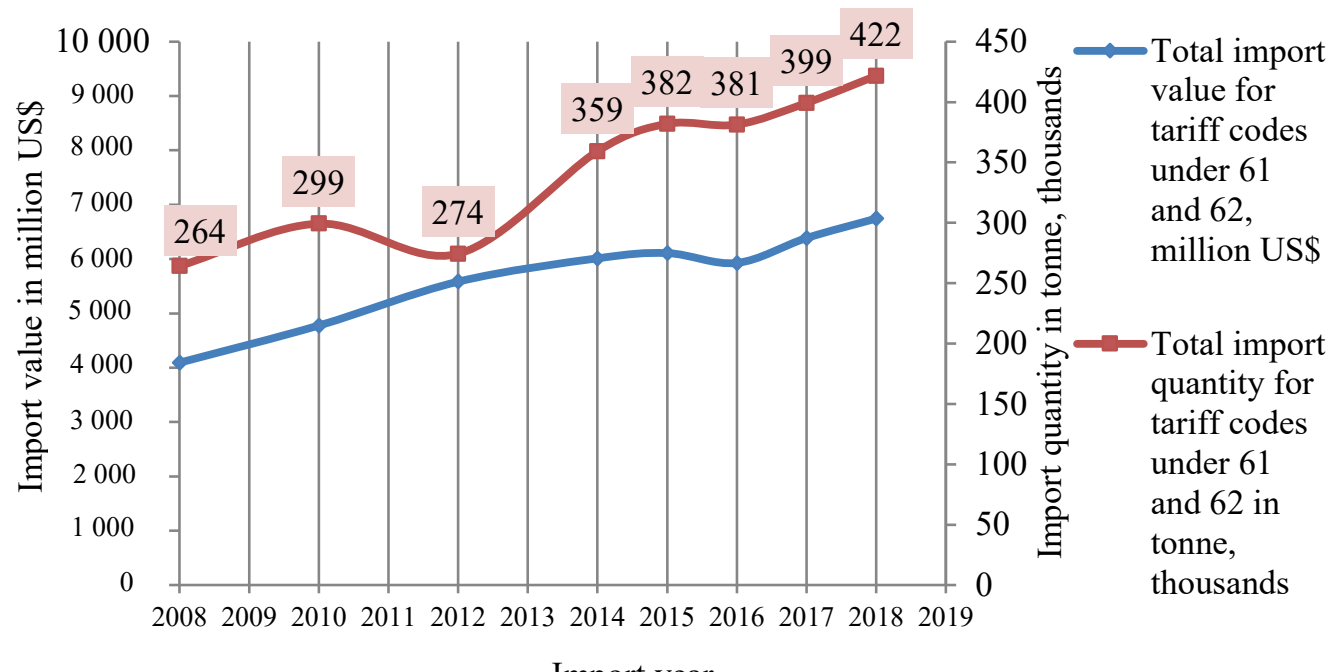

Fig. 1. Apparel import quantity and import value for tariff code 61 and 62 [32].

Total apparel products under tariff codes 61 and 62 are very large in number. Therefore, for simplification of this study, the apparel products listed under 61 and 62 have been categorised by broad apparel types as representative product categories in Australia (such as $\mathrm{knit} /$ woven jacket, knit/woven trouser, knit/woven shirt). All similar apparel is allocated in the same broad apparel category: for example, shirts, T-shirts and singlets are allocated to the 
broad category 'shirt'. Further allocation was according to fibre type, such as cotton, polyester, etc. Therefore, three parameters were considered to allocate the apparel in the broad representative category:

- Fabric type (knitted or woven),

- The similarity of apparel (e.g., shirts, T-shirts and singlets), and

- Fibre type (e.g., cotton, polyester, wool, acrylic, viscose, etc.).

It should be noted that most of the harmonised tariff schedule codes and sub-codes have specific fibre type, e.g., cotton, wool, etc. Some codes do not specify fibre types; in that case, we considered the explanation from the Australian Customs and Border Protection Service and world market consumption of fibres in order to allocate fibre quantity for unspecified fibres [33].

\subsection{Life Cycle Assessment Methodology}

The main aim of this study is to assess the environmental impacts of apparel consumption in Australia using the life cycle assessment methodology, following ISO14040/14044:2006. The details of the LCA studies are as follows.

Functional Unit: The functional unit of this study is 'the consumer use of one-kilogram apparel produced from different fibres mentioned in this study'. Consumer use refers to the use within the lifetime of apparel. This study considers the cycle from raw fibre production to end of life (EOL) of apparel. The impact assessment results of the functional unit were scaled up according to total apparel consumption in Australia by multiplication of the impact of the functional unit with the relevant apparel quantity.

System Boundary: The system boundary of this study began with raw fibre acquisition and continued to the end of life. The system boundary includes all life cycle stages of apparel, including overseas production, transport distribution, and user and disposal stages that occur in Australia (Fig. 2). Packaging of apparel, clothing accessories and transportation of chemical, auxiliaries and solid waste are excluded from the system boundary.

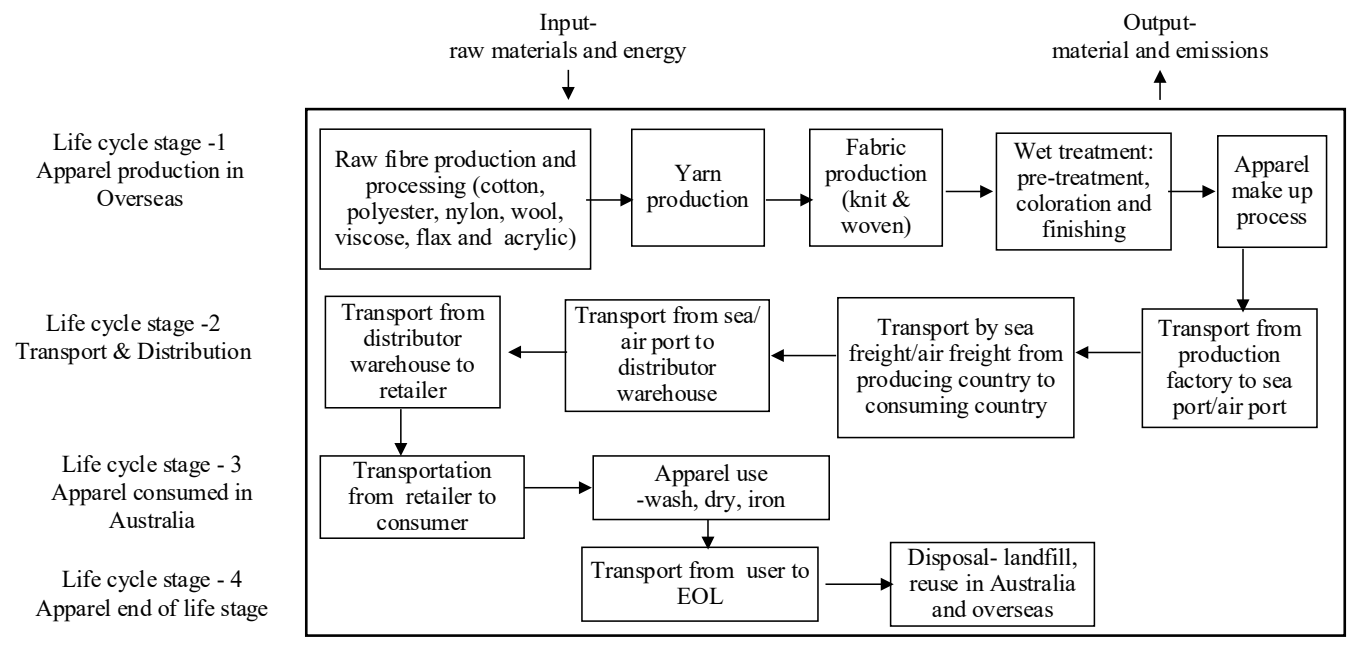

Fig. 2. System boundary of this study.

Cut off Approach: A cut off approach was used to model electricity mix by country of origin. If import quantity from any country is less than $1.5 \%$ of the total amount, then the 
specific quantity was proportionally distributed to the biggest apparel origin countries (Table A2 and Table A4).

Allocation: Some textile manufacturing processes produce co-products. For example, the wool fibre scouring process produces lanolin as a co-product with the main product of clean wool and the mass allocation was applied to wool fibre $(90 \%)$ and the lanolin co-product (10\%) [15]. For cotton production, the mass allocation of $40 \%$ for cotton fibre and $60 \%$ for cotton seeds was applied to allocate their impact burden [34]. Similarly, mass allocation was applied to flax fibre (5\%) and associated co-products (95\%) [35]. All other allocations adopted a default factor from background life cycle inventories.

Environmental Impact Categories and Impact Assessment Software: Life cycle impacts were assessed across climate change potential ( $\mathrm{CCP}, \mathrm{kg} \mathrm{CO}_{2} \mathrm{eq}$ ), acidification potential (AP, $\mathrm{kg} \mathrm{SO}_{2}$ eq), abiotic depletion potential (ADP, MJ), water depletion (WD, $\mathrm{m}^{3}$ ), and agricultural land occupation (ALO, $\mathrm{m}^{2} \mathrm{a}$ ). The CML (Centrum voor Milieukunde Leiden) baseline [36] was used for all impact categories, except for WD and ALO, which were quantified using the ReCipe Midpoint Method version 1.11 [37]. These impact categories were selected based on their common use in previously published references related to life cycle environmental impact assessments of textiles and clothing [10], [11], [38]. The life cycle assessment software OpenLCA developed by GreenDelta was used for life cycle impact assessment modelling.

Normalization: Impact assessment results of different impact categories were normalised on a per-capita basis. For normalization of CCP impact results, normalization factors were estimated from the total greenhouse gas emissions and population statistics of Australia [39], [40]. The WD impact result was normalized based on household water use and household population size data from the Australian Bureau of Statistics [41], [42]. A normalization factor of per capita impact of ALO was adopted from OECD.stat data of 32.53 hectares per capita according to agricultural land occupation [39]. A normalization factor for acidification was adopted from a reference report [43].

\subsection{Life Cycle Inventory}

Life cycle inventory data are incorporated with background data and foreground data. Foreground data were collected from secondary sources which include specific data to build a process or product model. Background datasets including materials, energy, resources, transport and waste management were taken from the Ecoinvent v3.1 database and the Australasian Unit Process database, AusLCI [44]. A pedigree matrix approach was used to assess quality of data sources, based on five indicators: reliability, completeness, temporal correlation, geographical correlation, and technological correlation. Data source was assessed with a quality-level score of 1 to 5 in terms of five data quality indicators [45], [46]. Data quality assessment was included in the supplementary information (Appendix Table A9). The quality of the inventory data was considered sufficient for this goal and the scope of this study. The life cycle inventory includes four different stages, as shown in Fig. 2.

\subsubsection{Textile production}

Ecoinvent v3 inventories used to model cotton, polyester, viscose, nylon, acrylic, wool and flax fibre production are presented in Table 1. Market share percentages of fibres for apparel manufacturing from different geographical locations were applied for the cotton and polyester fibre production model. For example, cotton fibre used for apparel manufacturing was $58 \%$, $4 \%, 2 \%$ and $36 \%$ from the geographic locations of China, the US, Australia and the rest of the world, respectively. A similar approach was applied to polyester raw materials production. 
All market share-related data were adopted from the UN Comtrade database and the world man-made fibre production by geographic region [32], [47].

TABLE 1. RAW Fibre Production INVENTORY

\begin{tabular}{|c|c|c|}
\hline Fibre type & Inventory type & $\begin{array}{l}\text { Ecoinvent v3 database and other references used to } \\
\text { model fibre production }\end{array}$ \\
\hline \multirow[t]{4}{*}{ Cotton } & Cotton fibre production & Cotton fibre $\{\mathrm{US}\} \mid$ cotton production $\mid$ Alloc Def, U (4 \%) \\
\hline & & Cotton fibres, ginned, at farm/CN U/AusSD/Link U (2\%) \\
\hline & & Cotton fibre $\{\mathrm{CN}\} \mid$ cotton production $\mid$ Alloc Def, $\mathrm{U}(58 \%)$ \\
\hline & & $\begin{array}{l}\text { Cotton fibre }\{\text { RoW }\} \mid \text { cotton production } \mid \text { Alloc Def, } U \\
(36 \%)\end{array}$ \\
\hline \multirow[t]{3}{*}{ Polyester } & PET resin production & $\begin{array}{l}\text { Polyethylene terephthalate, granulate, amorphous }\{\text { RoW }\} \mid \\
\text { production | Alloc Def, U (98\%) }\end{array}$ \\
\hline & & $\begin{array}{l}\text { Polyethylene terephthalate, granulate, amorphous }\{\text { RER }\} \mid \\
\text { production | Alloc Def, U }(2 \%)\end{array}$ \\
\hline & $\begin{array}{l}\text { Polyester fibre production from pet } \\
\text { resin through melt spinning }\end{array}$ & Polyester fibre production [48], [49] \\
\hline \multirow[t]{2}{*}{ Wool } & Wool production & Wool, sheep, at farm/US U/AusSD U [44] \\
\hline & Wool washing \& scouring & Wool washing \& scouring [48], [50] \\
\hline \multirow[t]{2}{*}{ Nylon } & Raw materials (resin) production & $\begin{array}{l}\text { Nylon } 6\{\mathrm{GLO}\} \mid \text { market for } \mid \text { Alloc Def, U } \\
\text { Nylon 6-6 }\{\mathrm{GLO}\} \mid \text { market for } \mid \text { Alloc Def, } \mathrm{U}\end{array}$ \\
\hline & $\begin{array}{l}\text { Nylon fibre production from resin } \\
\text { through melt spinning }\end{array}$ & Nylon fibre production [48] \\
\hline Viscose & Viscose fibre production & Viscose fibre $\{\mathrm{GLO}\} \mid$ viscose production $\mid$ Alloc Def, $\mathrm{U}$ \\
\hline \multirow[t]{2}{*}{ Acrylic } & Raw materials production & $\begin{array}{l}\text { Acrylonitrile }\{\mathrm{GLO}\} \mid \text { market for } \mid \text { Alloc Def, } \mathrm{U} \\
\text { Methyl methacrylate }\{\mathrm{GLO}\} \mid \text { market for } \mid \text { Alloc Def, } \mathrm{U}\end{array}$ \\
\hline & $\begin{array}{l}\text { Acrylic fibre production from } \\
\text { wet/dry spinning }\end{array}$ & Acrylic fibre production [48], [51] \\
\hline \multirow[t]{2}{*}{$\begin{array}{l}\text { Flax } \\
\text { (bast fibre) }\end{array}$} & Flax fibre production & $\begin{array}{l}\text { Kenaf fibre }\{\text { RoW }\} \mid \text { kenaf production | Alloc Def, U (bast } \\
\text { fibre) }\end{array}$ \\
\hline & Inventory data of flax fibre & {$[35],[52]$} \\
\hline
\end{tabular}

Raw material inventory datasets from different geographical locations for viscose and acrylic are not available in Ecoinvent v3. In this case, Ecoinvent v3 global datasets were used. Australia is one of the top wool-producing countries. The Australian life cycle inventory dataset for wool production was used as the wool production inventory. The textile production process inventories are included in Appendix Table A5.

\subsubsection{Transport and distribution stage}

Sea freight, air freight and road transport were used to model transport and distribution (T $\&$ D) stages of apparel supply chains. About $92 \%$ of imported apparels were transported by sea freight and the remaining $8 \%$ were transported by air freight [22]. The average travel distance by sea freight/air freight from apparel origin countries to Melbourne port, Australia, is shown in Table A7 in the Appendix. Assumptions were made for the average road distance from the production plant to the seaport/airport of the exporting country and seaport/airport 
of the importing country to import country retailer storage. Table 2 shows the inventory data and relevant Ecoinvent v3 database used to model T \& D.

TABLE 2. TRANSPORT AND DISTRIBUTION STAGE INVENTORY

\begin{tabular}{|c|c|c|}
\hline Type of inventory & $\begin{array}{l}\text { Inventory } \\
\text { data }\end{array}$ & Eco invent v3 \\
\hline $\begin{array}{l}\text { Local transport in production country by road (cloth } \\
\text { production plant to seaport) }\end{array}$ & $\begin{array}{l}500 \mathrm{~km} \\
\text { (assumed) }\end{array}$ & $\begin{array}{l}\text { Transport, freight, lorry, unspecified } \\
\{\text { GLO }\} \mid \text { market for } \mid \text { Alloc Def, } U\end{array}$ \\
\hline $\begin{array}{l}\text { International transport by sea freight }(92 \%) \text { (port of } \\
\text { production country to port of consuming country) }\end{array}$ & $8911 \mathrm{~km}$ & $\begin{array}{l}\text { Transport, freight, sea, transoceanic } \\
\text { ship }\{\text { GLO }\} \mid \text { market for } \mid \text { Alloc Def, } U\end{array}$ \\
\hline $\begin{array}{l}\text { International transport by air freight ( } 8 \% \text { ) (port of } \\
\text { production country to port of consuming country) }\end{array}$ & $7787 \mathrm{~km}$ & $\begin{array}{l}\text { Transport, freight, aircraft }\{\mathrm{GLO}\} \mid \\
\text { market for } \mid \text { Alloc Def, } U\end{array}$ \\
\hline $\begin{array}{l}\text { Local transport in consuming country by road (port } \\
\text { to distributor) }\end{array}$ & $\begin{array}{l}80 \mathrm{~km} \\
\text { (assumed) }\end{array}$ & $\begin{array}{l}\text { Transport, truck, } 3.5 \text { to } 16 \mathrm{t} \text {, fleet } \\
\text { average/AU U }\end{array}$ \\
\hline $\begin{array}{l}\text { Local transport in consuming country (Australia) by } \\
\text { road (distributor to retailer) }\end{array}$ & $\begin{array}{l}30 \mathrm{~km} \\
\text { (assumed) }\end{array}$ & $\begin{array}{l}\text { Transport, truck, } 3.5 \text { to } 16 \mathrm{t} \text {, fleet } \\
\text { average/AU U }\end{array}$ \\
\hline
\end{tabular}

\subsubsection{Consumer use stage}

Consumer use was modelled based on the data from the Australian Bureau of Statistics (ABS) [54] and other references [55]. According to the ABS, $26 \%$ of Australians wash their clothes with a full machine load, and around $80 \%$ of Australians use cold water. From this, it was estimated that $74 \%$ of Australians wash their clothes with a half-machine load and $20 \%$ of Australians use warm water during washing. Around $55 \%$ of households have tumble dryers. On average, in summer and winter, $31 \%$ of the population use dryers rarely, $24 \%$ use dryers frequently and the remaining $45 \%$ use dryers moderately [53], [55]. The consumer use stage inventory and other parameters used to model are presented in Table 3 and Table 4. Consumer washing, drying and ironing energy were calculated using Eq. 1 to Eq. 5.

$$
\begin{aligned}
& I=\left(100 \cdot A_{w}\right) / L_{h / f}, \\
& E_{w}=E_{w / c} \cdot I \cdot P_{w / c} \cdot P_{h / f}, \\
& D_{f / r / m}=A_{w} \cdot P_{d} \cdot P_{f / r / m} \cdot A_{f / r / m}, \\
& E_{d}=\left(I \cdot E_{c} \cdot D_{f / r / m}\right) / 100, \\
& E_{i}=\left(W_{i} \cdot T_{i}\right) / 1000,
\end{aligned}
$$

where

I $\quad$ impact per kg apparel based on machine load, \%;

$A_{w} \quad$ Apparel weight;

$L_{h / f} \quad$ washing machine load (half/full);

$E_{w} \quad$ energy required to wash per kg apparel;

$E_{w / c} \quad$ washing machine energy per warm/cold wash; 
$P_{w / c} \quad$ population to use warm/cold water during washing, \%;

$P_{h / f} \quad$ population to use half/full load during washing, $\%$;

$D_{f / r / m} \quad$ actual weights of apparel for dry frequently/rarely/moderately;

$P_{d} \quad$ population of dryer owner, \%;

$P_{f / r / m} \quad$ population to use dryer frequently/rarely/moderately, $\%$;

$A_{f / r / m} \quad$ actual dryer use among frequently/rarely/moderately;

$E_{d} \quad$ energy required drying per $\mathrm{kg}$ apparel;

$E_{c} \quad$ dryer energy per drying cycle;

$E_{i} \quad$ energy required to iron per $\mathrm{kg}$ apparel;

$W_{i} \quad$ iron machine power;

$T_{i} \quad$ iron time.

TABLE 3. CONSUMER USE STAGE INVENTORY

\begin{tabular}{|c|c|c|c|c|}
\hline $\begin{array}{l}\text { Consumer } \\
\text { stage }\end{array}$ & $\begin{array}{l}\text { Type of } \\
\text { inventory }\end{array}$ & Inventory & Comment & $\begin{array}{l}\text { AusLCI dataset used } \\
\text { to model }\end{array}$ \\
\hline $\begin{array}{l}\text { Consumer } \\
\text { transport }\end{array}$ & $\begin{array}{l}\text { Local } \\
\text { transport } \\
\text { (passenger } \\
\text { car) }\end{array}$ & $\begin{array}{l}\text { Transport distance from retailer } \\
\text { to consumer - } 10 \mathrm{~km} \text { (assumed) }\end{array}$ & & $\begin{array}{l}\text { Transport, passenger } \\
\text { car, diesel, EURO5, } \\
\text { city car/CH U/AusSD } \\
\text { U }\end{array}$ \\
\hline \multirow[t]{4}{*}{ Wash } & Electricity & $\begin{array}{l}\text { Energy consumption } 0.24 \\
\mathrm{kWh} / \text { cold wash and } 2.1 \\
\mathrm{kWh} / \text { warm wash were } \\
\text { calculated for } 2 \text {-star washing } \\
\text { machines }[56]\end{array}$ & $\begin{array}{l}\text { Eq. (1) and Eq. (2) for } \\
\text { energy required to wash } \\
\text { per kg apparel. }\end{array}$ & $\begin{array}{l}\text { Electricity, low } \\
\text { voltage, } \\
\text { Australian/AU U }\end{array}$ \\
\hline & Water & $\begin{array}{l}\text { Average } 90 \mathrm{~L} \text { water per wash } \\
\text { for } 6 \mathrm{~kg} \text { machine load [56] }\end{array}$ & $\begin{array}{l}\text { Water consumption was } \\
\text { calculated based on one } \\
\text { kg apparel. }\end{array}$ & $\begin{array}{l}\text { Tap water, at } \\
\text { user/RER } \\
\text { U/adapted/AU U }\end{array}$ \\
\hline & Detergent & $\begin{array}{l}50 \mathrm{~g} \text { per wash for } 5 \mathrm{~kg} \text { load } \\
\text { machine [57] }\end{array}$ & $\begin{array}{l}\text { Detergent consumption } \\
\text { was calculated based on } \\
\text { one } \mathrm{kg} \text { apparel ( } 10 \mathrm{~g} \text { for } \\
\text { one } \mathrm{kg} \text { apparel). }\end{array}$ & $\begin{array}{l}\text { From detergent } \\
\text { production model } \\
\text { (TABLE A8) }\end{array}$ \\
\hline & Wastewater & $\begin{array}{l}\text { For simplification we } \\
\text { considered same amount of } \\
\text { water will enter the wastewater } \\
\text { system as used for washing } \\
\text { machine. }\end{array}$ & & $\begin{array}{l}\text { Treatment, sewage, } \\
\text { from residence, to } \\
\text { wastewater treatment, } \\
\text { class } 2 / \mathrm{CH} \text { U/AusSD } \\
\mathrm{U}\end{array}$ \\
\hline Dry & Electricity & Average & $\begin{array}{l}\text { Eq. (1), Eq. (3) and Eq. } \\
\text { (4) for energy required } \\
\text { drying per kg apparel. }\end{array}$ & $\begin{array}{l}\text { Electricity, low } \\
\text { voltage, } \\
\text { Australian/AU U }\end{array}$ \\
\hline Iron & Electricity & 1600 Watt [22] & $\begin{array}{l}\text { Eq. (5) for Energy } \\
\text { required to iron per kg } \\
\text { apparel. }\end{array}$ & $\begin{array}{l}\text { Electricity, low } \\
\text { voltage, } \\
\text { Australian/AU U }\end{array}$ \\
\hline
\end{tabular}


TABle 4. Parameters Used to Model Consumer Use Stage

\begin{tabular}{|c|c|}
\hline Washing machine load & $\begin{array}{l}26 \% \text { of the population use full load during washing. Assumed } 74 \% \text { population } \\
\text { use half load [55] }\end{array}$ \\
\hline Water temperature & $80 \%$ of the population use cold water during washing [55] \\
\hline Washing machine size (capacity) & The most common washing machine capacity used in Australia is $6 \mathrm{~kg}$ [55] \\
\hline Dryer ownership & $55 \%[55]$ \\
\hline Dryer use frequency & $\begin{array}{l}31 \% \text { of the population use dryer infrequently; } 4 \% \text { of the population use dryer } \\
\text { regularly; } 45 \% \text { of the population use dryer reasonably [55] }\end{array}$ \\
\hline Apparel wash to dryer use ratio & Adopted from reference [22] \\
\hline Apparel wash to iron use ratio & Adopted from reference [22] \\
\hline Ironing time & Adopted from reference [22] \\
\hline $\begin{array}{l}\text { Lifetime of apparel and total } \\
\text { number of washes }\end{array}$ & $\begin{array}{l}\text { Shirt (lifetime } 1 \text { year and total number of washes } 50 \text { ) } \\
\text { Dress (lifetime } 1 \text { year and total number of washes } 15 \text { ) } \\
\text { Trousers (lifetime } 2 \text { years and total number of washes 92) } \\
\text { Nightwear, dressing gown (lifetime } 2 \text { years and total number of washes 50) } \\
\text { Sportswear/swim wear (lifetime } 1 \text { year and total number of washes 24) } \\
\text { Suit/ensembles (lifetime } 2 \text { years and total number of washes 40) } \\
\text { Jacket/sweater (lifetime } 3 \text { years and total number of washes } 40 \text { ) } \\
\text { Under apparel (lifetime } 1 \text { year and total number of washes 38) } \\
\text { Scarves (lifetime } 2 \text { years and total number of washes 12) } \\
\text { Socks (lifetime } 1 \text { year and total number of washes 104) } \\
\text { Gloves (lifetime } 2 \text { years and total number of washes 4) } \\
\text { [22], [59] }\end{array}$ \\
\hline
\end{tabular}

\subsubsection{End of life}

In Australia, used clothing is mainly collected by charities and clothing recyclers. According to a discussion paper on textile waste in Australia, over 50 million kilograms of textile waste was collected through charity bins by different charity organisations and clothing recyclers. About 12.5 million kilograms of the collected textile waste was unsuitable for recycling and reuse, and was sent to landfill. The rest was recovered by recycling and reusing through charity shops and recycling organisations [60]. From this information it is assumed that $25 \%$ of the textile waste is disposed of through landfill and the remaining $75 \%$ is recovered through recycling and reuse.

In order to model the end of life scenario, it was assumed that $35 \%$ of the disposed textiles are reused in Australia through charity shops and $40 \%$ are reused overseas through exportation. Australia has a big international market for used textiles [60]. The relevant tariff code of used clothing (worn clothing) is 630900 . The major importers of used clothing from Australia are the United Arab Emirates, Malaysia and Pakistan [32], [60]. The end of life inventory is reported in Table 5. 
TABLE 5. END OF LIFE STAGE INVENTORY

\begin{tabular}{|c|c|c|c|c|}
\hline & Inventory type & Inventory & Unit & $\begin{array}{l}\text { Dataset used to } \\
\text { model }\end{array}$ \\
\hline \multirow[t]{2}{*}{$\begin{array}{l}\text { Landfill }(25 \% \\
\text { of the used } \\
\text { textiles })\end{array}$} & Landfill amount & $\begin{array}{l}\text { From use stage }(25 \% \text { of } \\
\text { the disposed textile })\end{array}$ & $\mathrm{kg}$ & $\begin{array}{l}\text { Waste treatment, } \\
\text { textiles, at } \\
\text { landfill/AU U }\end{array}$ \\
\hline & Transportation to landfill & 100 km (assumed) & $\mathrm{kg} \mathrm{km}$ & $\begin{array}{l}\text { Transport, truck, } 16 \\
\text { to } 28 \mathrm{t} \text {, fleet } \\
\text { average/AU U }\end{array}$ \\
\hline \multirow[t]{2}{*}{$\begin{array}{l}\text { Reuse in } \\
\text { Australia ( } 35 \% \\
\text { of the used } \\
\text { textiles) }\end{array}$} & $\begin{array}{l}\text { Electricity use for reuse } \\
\text { (collection, processing, and } \\
\text { distribution of used clothing) }\end{array}$ & $\begin{array}{l}1.7 \mathrm{kWh} / \mathrm{kg} \text { used cloth } \\
\text { (Based on a SATC } \\
\text { (salvation army trading } \\
\text { company report) [61] }\end{array}$ & $\mathrm{kWh}$ & $\begin{array}{l}\text { Electricity, medium } \\
\text { voltage }\{A U\} \mid \text { market } \\
\text { for } \mid \text { Alloc Def, } U\end{array}$ \\
\hline & $\begin{array}{l}\text { Transportation to local reuse } \\
\text { (in Australia) by truck }\end{array}$ & 30 km (assumed) & $\mathrm{kg} \mathrm{km}$ & $\begin{array}{l}\text { Transport, truck, } 16 \\
\text { to } 28 \mathrm{t} \text {, fleet } \\
\text { average/AU U }\end{array}$ \\
\hline \multirow[t]{2}{*}{$\begin{array}{l}\text { Reuse in } \\
\text { overseas ( } 40 \% \\
\text { of the used } \\
\text { textiles) }\end{array}$} & $\begin{array}{l}\text { Transportation to overseas } \\
\text { reuse by ship }\end{array}$ & $\begin{array}{l}10000 \mathrm{~km} \text { (average sea } \\
\text { distance to main import } \\
\text { country of used apparel } \\
\text { from Australia [62] }\end{array}$ & $\mathrm{kg} \mathrm{km}$ & $\begin{array}{l}\text { Transport, } \\
\text { transoceanic freight } \\
\text { ship/OCE U/AusSD } \\
U\end{array}$ \\
\hline & $\begin{array}{l}\text { Transport for reuse overseas } \\
\text { by truck }\end{array}$ & 30 km (assumed) & $\mathrm{kg} \mathrm{km}$ & $\begin{array}{l}\text { Transport, truck, } 16 \\
\text { to } 28 \mathrm{t} \text {, fleet } \\
\text { average/AU U }\end{array}$ \\
\hline
\end{tabular}

\subsection{Estimation of Environmental Impact of Apparel Consumption in Australia}

In order to estimate environmental impact of apparel consumption, the results of the functional unit (use of one-kilogram apparel produced from different fibres) were scaled up based on the total consumption of apparel in Australia of 2015 in terms of fibre and apparel broad category. Apparel quantity for 2015 was considered due to the unavailability of quantity breakdown data of different apparel for recent years at the time of this study. The overall environmental impact of apparel consumption was estimated by using Eq. 6 and Fig. 3. This was done by multiplication of the environmental impact per functional unit of each apparel broad category and total quantity of apparel of these broad categories.

$$
C=\sum_{n=1}^{N}\left[\left(I_{n} \cdot Q_{n}\right)_{k n i t \text { apparel }}+\left(I_{n} \cdot Q_{n}\right)_{\text {woven apparel }}\right],
$$

where

$C \quad$ overall environmental impact;

$N$ the number of apparel broad representative category and $n$ varies from 1 to $N$ depending on the number of apparel broad categories;

$I_{n} \quad$ environmental impact of apparel broad category per functional unit (in terms of fibre type);

$Q_{n} \quad$ total quantity of apparel broad category (in terms of fibre type). 


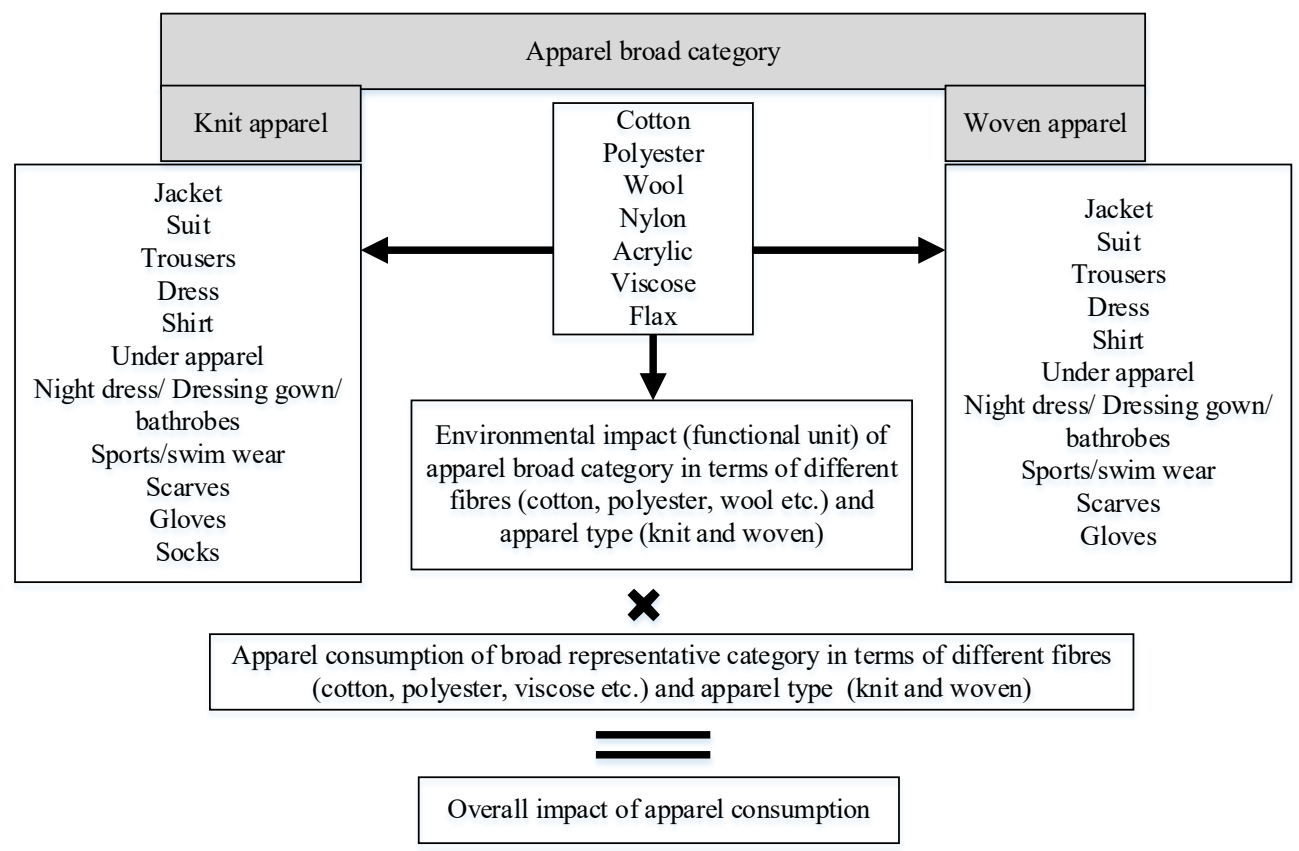

Fig. 3. Scale up environmental impact at the national level.

The environmental impact assessment results of apparel consumption were normalised on a per capita per year basis. For normalisation, reference characterisation factors of different impact categories were used with respect to Australian geographical scale. A rough estimation of year to year impact contribution per capita has been done for 2014 to 2018 . Apparel import data and population for the corresponding years were used for this estimation. The same market share of fibres was assumed for these years. To estimate change of year-on-year impact, overall impact values of all impact categories for surrounding years of 2015 were determined using total apparel quantity of 2015 and relevant impact values of impact categories: for example, total impact for apparel consumption in $2016=$ [apparel consumption in 2016 times total impact for apparel consumption in 2015 / apparel consumption in 2015]. These impact values were divided by the population of the year to estimate per capita/year impact and change of impact contribution year-on-year.

\subsection{Analysis of Impact Contribution}

The environmental impact contributions were analysed in terms of fibre type, apparel type, life cycle stages, sub-stages and energy used for apparel production stages. This analysis was done by breaking down impact results according to apparel type, fibre type and different stages and sub-stages. Overall impact contribution of different fibres respecting total consumption was estimated using Eq. 7. Impact contribution of different stages of life cycle in terms of total apparel consumption and fibre type was estimated using Eq. 8, Eq. 9 and Eq. 10. Impact contributions of sub-stages of the life cycle were done by averaging the impact of sub-stages of life cycle of apparel. In this case, to avoid complicity of using all types of apparel, only apparel with a high market share was used. 


$$
\begin{aligned}
& I_{c a}=\left(100 \cdot I_{k m}\right) / I_{f}, \\
& I_{c}=\left(I_{c k}+I_{c w}\right) / 2, \\
& I_{a i}=\left(I_{c}+I_{p}+I_{w}+I_{a}+I_{n}+I_{f}\right) / 6, \\
& I_{l c}=\left(I_{c a} \cdot I_{a i}\right) / 100,
\end{aligned}
$$

where

$I_{c a} \quad$ impact contribution of fibre (cotton/polyester/wool/acrylic/nylon/viscose/flax) in terms of total apparel consumption, $\%$;

$I_{k m}$ total impact of knit and woven apparel in terms of specific fibre type (cotton/polyester/wool/acrylic/nylon/viscose/flax);

$I_{f} \quad$ total impact of knit and woven apparel in terms of all fibre type;

$I_{c} \quad$ average impact contribution from life cycle stages (production/use/transport/end of life) of all apparels in terms of fibre type cotton [same equation applies for all fibre type, polyester $\left(I_{p}\right)$, wool $\left(l_{w}\right)$, acrylic $\left(I_{a}\right)$, nylon $\left(I_{n}\right)$ and flax $\left.\left(I_{f}\right)\right]$;

$I_{c k} \quad$ impact contribution from life cycle stages (production/use/transport/end of life) of knit apparel in terms of fibre type, $\%$;

$I_{c w} \quad$ impact contribution from life cycle stages (production/use/transport/end of life) of woven apparel in terms of fibre type, $\%$;

$I_{a i} \quad$ average impact of all fibres in terms of life cycle stage (production/use/transport/end of life);

$I_{l c} \quad$ impact contribution of different stages of life cycle in terms of total apparel consumption and fibre type, $\%$.

\section{RESUlts}

\subsection{Estimated Apparel Consumption in Australia}

The total apparel consumption was estimated to be 381977000 kilograms (import quantity under tariff codes 61 and 62) according to the UN Comtrade database. Accordingly, apparel consumption per capita per year was 16 kilograms based on 2015 population of 23.79 million.

The apparel product descriptions listed under harmonized tariff codes 61 and 62 are reported in Table 6 with the respective 11 broad representative groups. Market share of apparel with a breakdown of broad apparel types and fibre types is presented in Fig. 4. Their quantities are presented in the Appendix Table A1.

According to the data on apparel imported into Australia in 2015, 78.40\% came from China, $10.47 \%$ from Bangladesh, $3.18 \%$ from Vietnam, $3.13 \%$ from India, $3.13 \%$ from Indonesia, and $1.69 \%$ from Cambodia (Table A2, Appendix) [32]. This estimation was done using $1.5 \%$ cut-off criteria. The main fibres used for apparel manufacturing are cotton, polyester, wool, nylon, acrylic, viscose and flax, with shares of (estimated) $53.97 \%, 31.79 \%$, $1.57 \%, 0.29 \%, 3.45 \%, 3.4 \%$ and $5.34 \%$, respectively, as shown in Fig. 4(b). 
TABLE 6. APPAREL BROAD CATEGORIES

\section{Apparel description mentioned under harmonised tariff codes 61 and 62}

Apparel broad category

(knit and woven)

Jerseys, pullovers, cardigans, waistcoats jackets, blazers, overcoats, car coats, capes, cloaks, anoraks (including ski jackets), windcheaters, wind-jackets and similar

Sweater \& Jackets articles

\begin{tabular}{ll}
\hline Suits, ensembles & Suit/ensembles \\
\hline $\begin{array}{l}\text { Trousers, bib and brace overalls, breeches shorts, skirts, divided skirts, and all types } \\
\text { of trousers, pants and bottoms }\end{array}$ & Trousers \\
\hline Women's or girls' dresses & Dresses \\
\hline T-shirts, shirt, singlets, and blouse & Shirt \\
\hline Underpants, briefs, panties, brassieres, girdles, corsets, braces, suspenders & Undergarments \\
\hline $\begin{array}{l}\text { Nightshirts, pyjamas, slips, nightdresses, bathrobes, dressing gowns and similar } \\
\text { articles }\end{array}$ & Nightdress \\
\hline Swimwear, tracksuits, ski suits & Sports/swim wear \\
\hline $\begin{array}{l}\text { Shawls, scarves, mufflers, mantillas, veils, handkerchiefs, ties, bow ties and cravats } \\
\text { Gloves, mittens and mitts }\end{array}$ & Scarves \\
\hline $\begin{array}{l}\text { Pantyhose, tights, stockings, socks and other hosiery, including graduated } \\
\text { compression hosiery (for example, stockings for varicose veins) and footwear without } \\
\text { applied soles }\end{array}$ & Socks \& tights \\
\hline
\end{tabular}

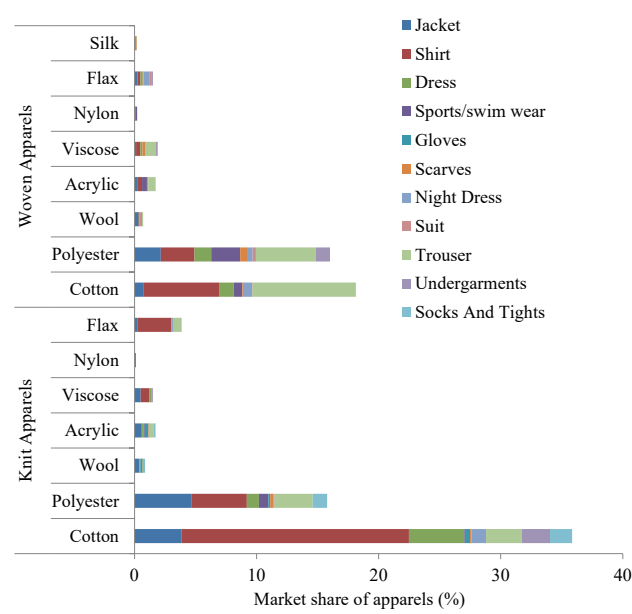

(a)

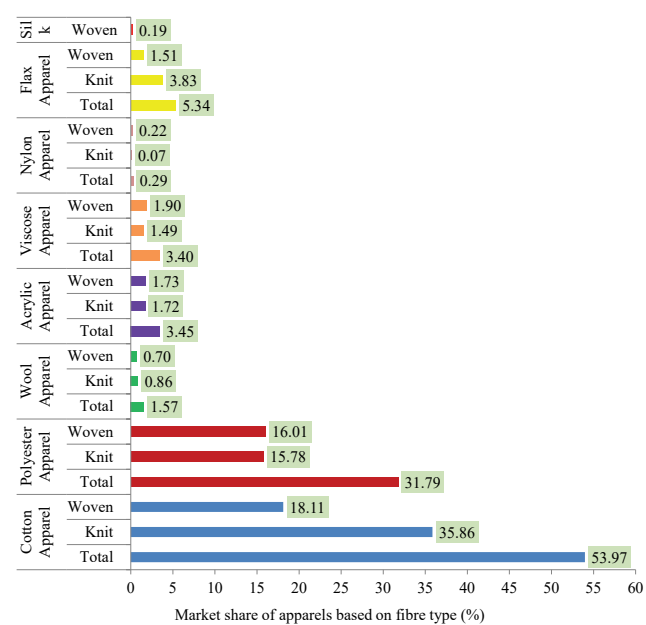

(b)

Fig. 4. Market volume of apparel in terms of apparel type (a) and fibre type (b).

It should be noted that the market share of silk apparel is minimal $(0.19 \%)$ compared to other fibre apparel; therefore, for simplification, silk apparel was not considered in this study. Fig. 4(a) presents the market volume of woven and knit apparel broad representative groups. Market volume of knit apparel and woven apparel is about $60 \%$ and $40 \%$, respectively. 
The broad categories of cotton knit shirts, cotton woven trousers, and polyester trousers were estimated to be consumed in the high amounts, at approximately $33 \%$ of total apparel consumption. Detailed breakdown of apparel consumption in Australia is presented in the Appendix (Table A1).

\subsection{Environmental Impact of Apparel - In Terms of per Functional Unit}

The environmental impacts of different apparel representative broad categories in terms of per functional unit (1 kg apparel) are presented in Fig. 5 to Fig. 9. Environmental impact of knit apparel is comparatively lower than woven apparel due to the additional processes involved in woven apparel manufacturing. CCP impact of apparel made from wool, nylon, acrylic and polyester is comparatively higher than apparel made from cotton, viscose and flax, whereas, WD impact from cotton apparel is significantly higher than other fibre apparel. This is because the WD impact value is influenced by the water consumption during fibre cultivation/production, and the cotton production requires the highest amount of water among the fibres studied. Man-made fibre apparel has comparatively high CCP impact due to the high energy required for the raw fibre production. Wool apparel also has comparatively high CCP impact due to methane emission during wool production. Cotton and flax apparel has comparatively less CCP impact.

Apparel produced from wool fibres contributes comparatively high impact on AP and ALO (Fig. 8 and Fig. 9). The impact on ALO is mainly due to the direct land used for raw fibre production. Land used for sheep production for wool fibre is the highest contributor to ALO, followed by cotton crop cultivation. Flax apparel contributes the lowest impact to AP and ALO, which is mainly due to the lesser impact from the flax fibre raw material production process.
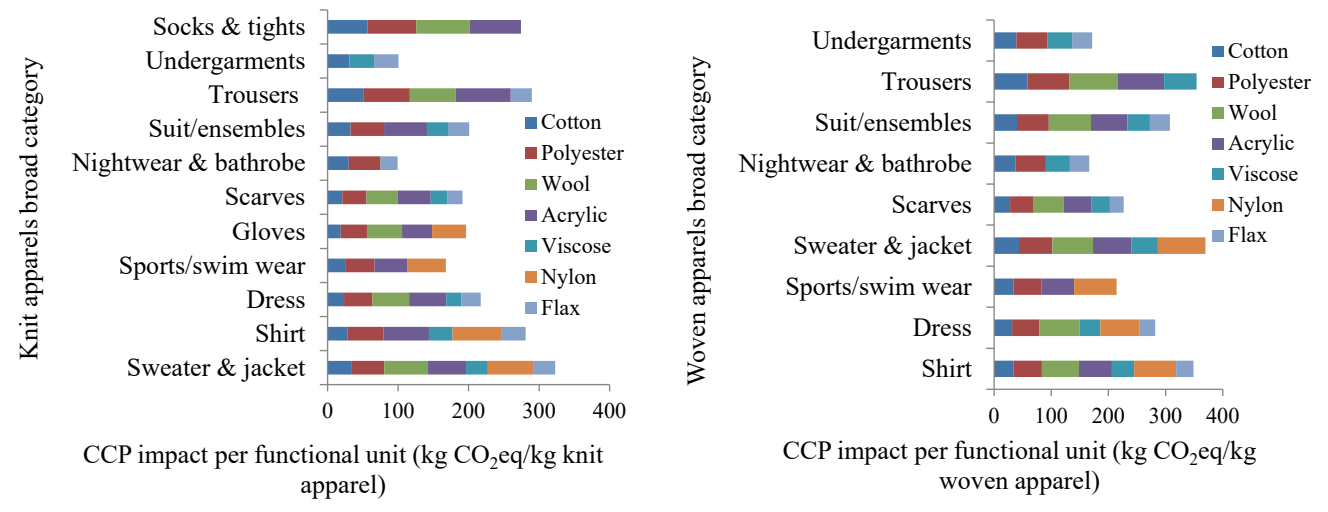

Fig. 5. CCP impact (per kilogram apparel) of knit and woven apparel broad categories. 


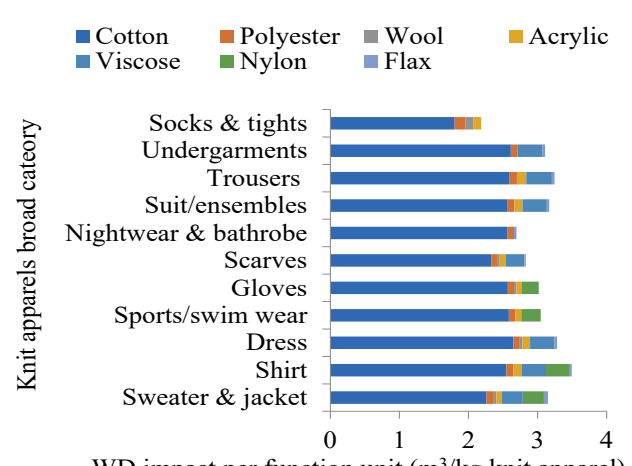

WD impact per function unit $\left(\mathrm{m}^{3} / \mathrm{kg}\right.$ knit apparel)

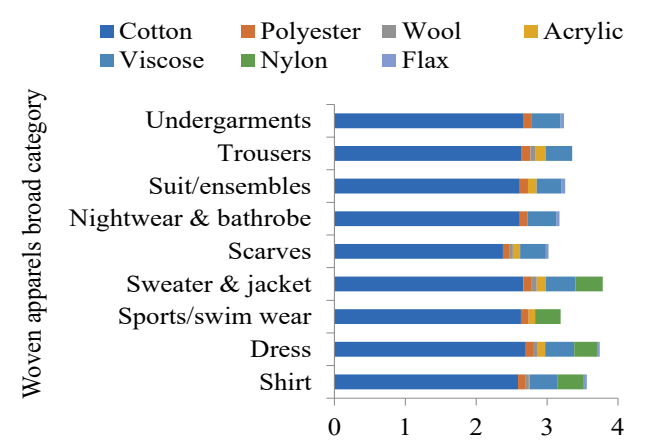

WD impact per functional unit $\left(\mathrm{m}^{3} / \mathrm{kg}\right.$ woven apparel)

Fig. 6. WD impact (per kilo-gram apparel) of knit and woven apparel broad categories.

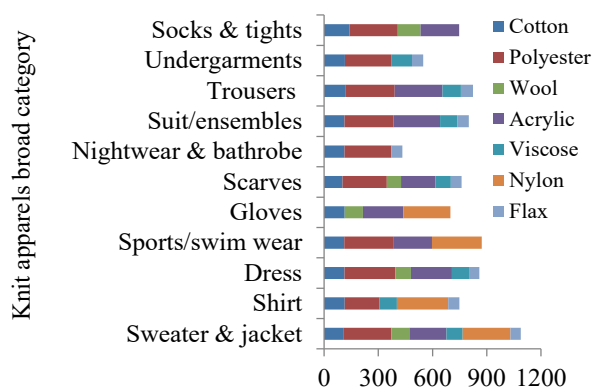

ADP impact per functional unit $(\mathrm{MJ} / \mathrm{kg}$ knit apparel)

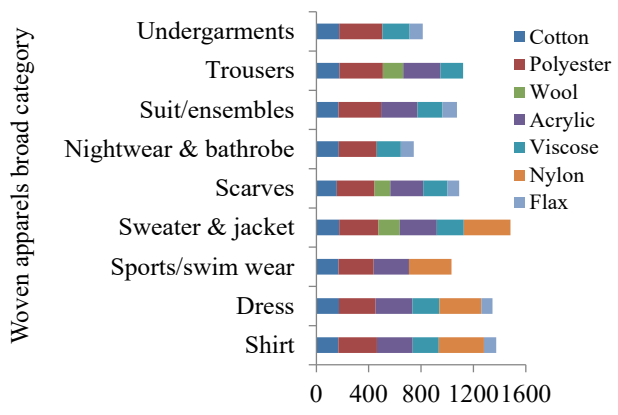

ADP impact per functional unit $(\mathrm{MJ} / \mathrm{kg}$ woven apparel)

Fig. 7. ADP impact (per kilo-gram apparel) of knit and woven apparel broad categories.

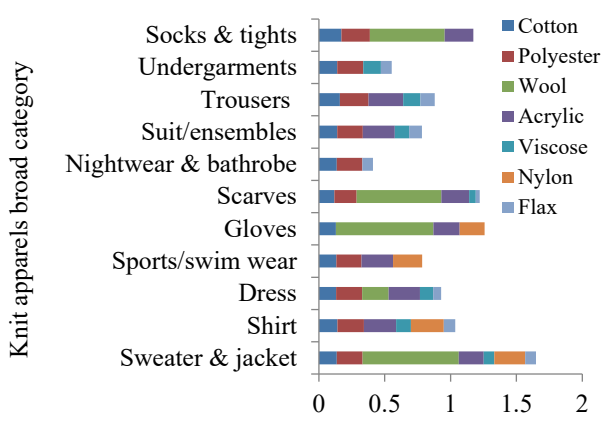

AP impact per functional unit $\left(\mathrm{kg} \mathrm{SO}_{2} \mathrm{eq} / \mathrm{kg} \mathrm{knit}\right.$ apparel)

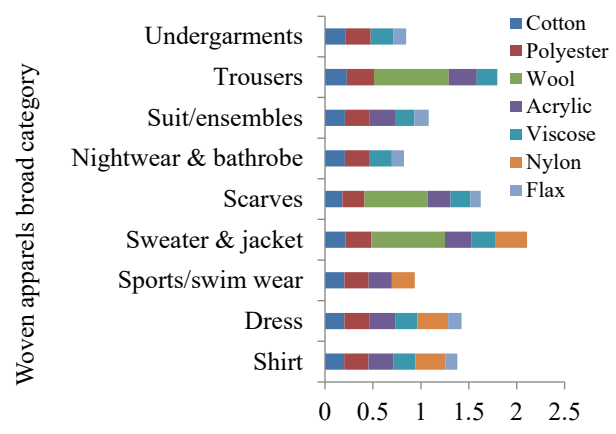

AP impact per functional unit $\left(\mathrm{kg} \mathrm{SO}_{2} \mathrm{eq} / \mathrm{kg}\right.$ wover apparel)

Fig. 8. AP impact (per kilo-gram apparel) of knit and woven apparel broad categories. 


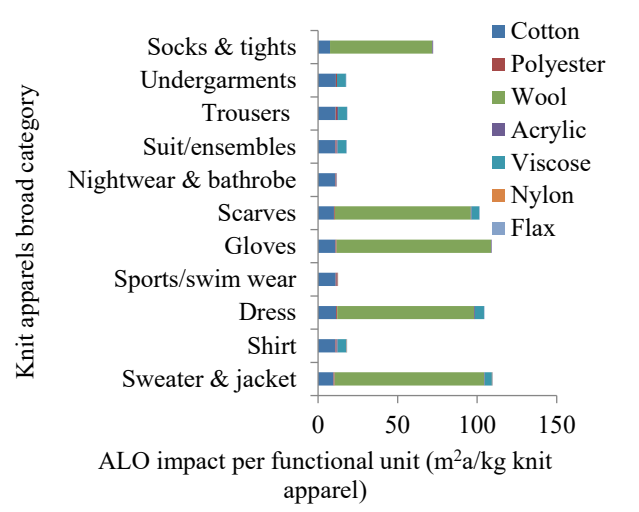

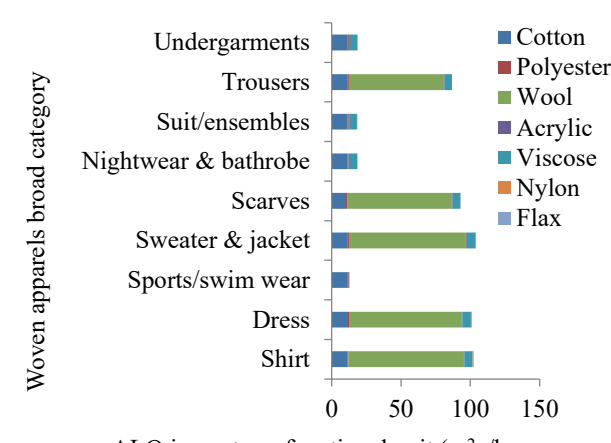

ALO impact per functional unit $\left(\mathrm{m}^{2} \mathrm{a} / \mathrm{kg}\right.$ woven apparel

Fig. 9. ALO impact (per kilo-gram apparel) of knit and woven apparel broad categories.

\subsection{Environmental Impact of Apparel: Total Apparel Consumption in Australia}

Environmental impact of apparel consumption in Australia was modelled by scaling up the impact assessment results per functional unit in terms of fibre type and apparel type. The estimated scaled up total impact values and per capita impact values are shown in Table 7.

TABLE 7. The Estimated SCALED UP IMPACT VALUES FOR APPAREL CONSUMPTION

\begin{tabular}{|c|c|c|c|}
\hline Impact category & Total impact & $\begin{array}{l}\text { Per capita } \\
\text { impact } \\
\text { contribution }\end{array}$ & Unit \\
\hline Climate change potential (CCP) & 16607027596 & 698.07 & $\mathrm{~kg} \mathrm{CO}_{2} \mathrm{eq}$ \\
\hline Acidification potential (AP) & 73589236 & 3.09 & $\mathrm{~kg} \mathrm{SO}_{2} \mathrm{eq}$ \\
\hline Water depletion (WD) & 544619558 & 22.89 & $\mathrm{~m}^{3}$ \\
\hline Abiotic resource depletion potential - fossil fuel (ADP) & 68483834597 & 2878.68 & MJ \\
\hline Agricultural land occupation (ALO) & 2854070860 & 119.97 & $\mathrm{~m}^{2} \mathrm{a}$ \\
\hline
\end{tabular}

\subsection{Environmental Impact of Apparel - Per Capita and Normalised Impact in Australia}

Table 7 also presents the per capita impact contribution due to total apparel consumption. The annual CCP for apparel consumption in Australia was calculated to be $698 \mathrm{~kg} \mathrm{CO}_{2}$ eq per capita, of which $405 \mathrm{~kg} \mathrm{CO}_{2} \mathrm{eq}(698 \cdot 58.05 \%) \mathrm{CCP}$ was associated with the production stage overseas, $277 \mathrm{~kg} \mathrm{CO}_{2}$ eq [698·(38.14+1.56)\%] CCP was associated with the emissions released in Australia due to consumer use and end of life activities, and the remaining $16 \mathrm{~kg}$ $\mathrm{CO}_{2}$ eq CCP was for apparel transportation. This estimation was done using the overall impact contribution of different stages of the life cycle as shown in Table 8. The $277 \mathrm{~kg} \mathrm{CO}$ eq emissions account for $1.23 \%$ of total CCP per capita in Australia, which is 22.4 tonnes $\mathrm{CO}_{2}$ eq. The 22.4 tonnes $\mathrm{CO}_{2}$ eq per capita in 2015 was estimated from the total greenhouse gas emission 535173670 tonnes $\mathrm{CO}_{2}$ eq and a population 23795663 in 2015 [39], [40].

The total impact of WD for apparel consumption per capita is $22.89 \mathrm{~m}^{3}$, of which $3.62 \mathrm{~m}^{3}$ (3.62 tonnes) occurred in Australia due to consumer apparel use activities. The yearly number of wash cycles per household in Australia is 240 [41]. This is equivalent to 21600 litres (21.6 tonnes) of water consumption yearly for clothing washing, assuming 90 litres water consumption per wash cycle [56]. The average household size in Australia is 2.6 to 3 persons 
[42]. Using this data, it can be estimated that there is about $7.2 \mathrm{~m}^{3}$ of water consumption yearly per person for all types of cloth washing, which includes home textiles and apparel.

TABLE 8. OVERALl IMPACT CONTRIBUtion OF DifFERENT STAGES OF LIFE CYCLE FOR ALL FIBRES

\begin{tabular}{lllll}
\hline $\begin{array}{l}\text { Environmental } \\
\text { Impact Categories }\end{array}$ & $\begin{array}{l}\text { Production, } \\
\mathbf{\%}\end{array}$ & Use, $\%$ & $\begin{array}{l}\text { Transportation, } \\
\mathbf{\%}\end{array}$ & $\begin{array}{l}\text { End of life, } \\
\mathbf{\%}\end{array}$ \\
\hline CCP & 58.05 & 38.14 & 2.25 & 1.56 \\
WD & 83.03 & 13.56 & 1.17 & 2.24 \\
ADP & 84.17 & 3.38 & 8.30 & 4.15 \\
AP & 83.52 & 11.39 & 3.11 & 1.98 \\
ALO & 85.56 & 12.21 & 0.60 & 1.63 \\
\hline
\end{tabular}

Similarly, agricultural land occupation for apparel consumption was calculated to be $119.97 \mathrm{~m}^{2} \mathrm{a}$ per capita. The contribution to this in Australia was limited, at $16.6 \mathrm{~m}^{2} \mathrm{a}$ (0.00166 ha), which is very small compared to the per capita impact of ALO 32.53 hectares, according to OECD.stat data on agricultural land occupation [39]. The impact of ADP (fossil fuel) was $2878.68 \mathrm{MJ}$ per capita in terms of total apparel consumption.

The annual per-capita acidification potential impact for apparel consumption was calculated to be $3.09 \mathrm{~kg} \mathrm{SO}$ eq, of which $0.41 \mathrm{~kg} \mathrm{SO}$ eq were impacts in Australia, accounting for $0.33 \%$ of total individual AP impact in Australia. Individual AP impact in Australia was $123 \mathrm{~kg} \mathrm{SO}$ eq per capita/year in Australia [43].

Fig. 10 shows the change of impact contribution (\%) per capita/year for all impact categories arising from the change of apparel consumption year-on-year. This estimation was based on the estimated impact of apparel consumption in 2015. It can be noted that the impact contribution of all impact categories increases with the increase of per capita apparel consumption. Per capita apparel consumption in 2018 increased by approximately $5 \%, 24 \%$ and $35 \%$ from earlier years 2015, 2010 and 2008, respectively. Overall environmental impact due to apparel consumption during these years changed in the same order.

\subsection{Environmental Impact Analysis Based on the Impact Contributor}

\subsubsection{Impact contribution of fibres and apparel life cycle stages}

The share of relative environmental impact contribution in respect of apparel life cycle stages and is different fibres presented in Table 8 and Table 9, respectively. The impact contribution is influenced by the market share of different type of fibres consumed for apparel manufacturing in Australia. Cotton apparel contributes the highest impact in respect of most impact categories due to its highest market share for apparel production. Polyester apparel contributes to the highest impact of ADP, followed by cotton and acrylic apparel (Table 9). The apparel production stage contributes the highest impact on all impact categories. End of life and transportation stages contribute a very small impact (Table 8). The use stage contributes $38.14 \%$ of CCP impact. Fig. 11 presents the breakdown of total impact contribution in terms of the impact of life cycle stages and apparel fibre type, as stated in Table 8 and Table 9. The apparel production stage contributes the highest impact of all categories, followed by the use stage. Transportation and EOL stages contribute lesser impact compared to other stages. The ADP impact of the transportation stage is $8.3 \%$, which is higher than that of the use stage (Table 8). Among all knit apparel categories, the impact contribution from the cotton shirt and polyester jacket categories is comparatively high. 
Similarly, cotton and polyester trousers contribute the highest impact among all woven apparel categories. This impact contribution was influenced by market volume and the impact per functional unit.

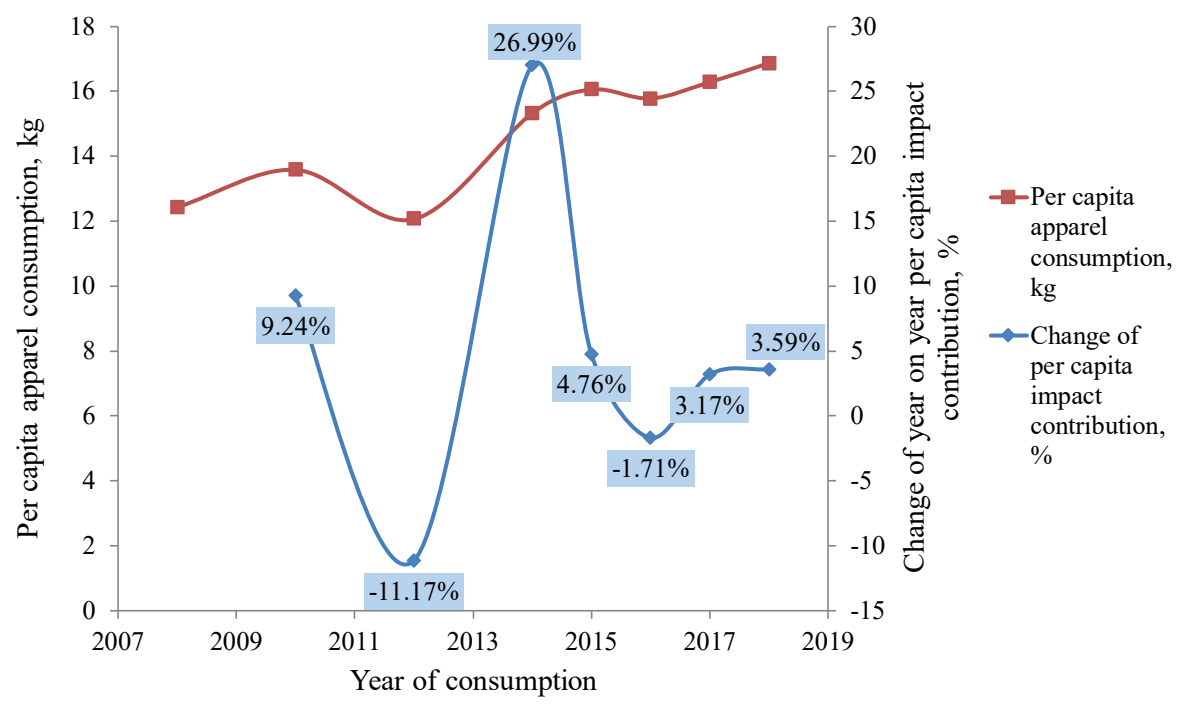

Fig. 10. Change of impact contribution per capita-year from 2008 to 2018.

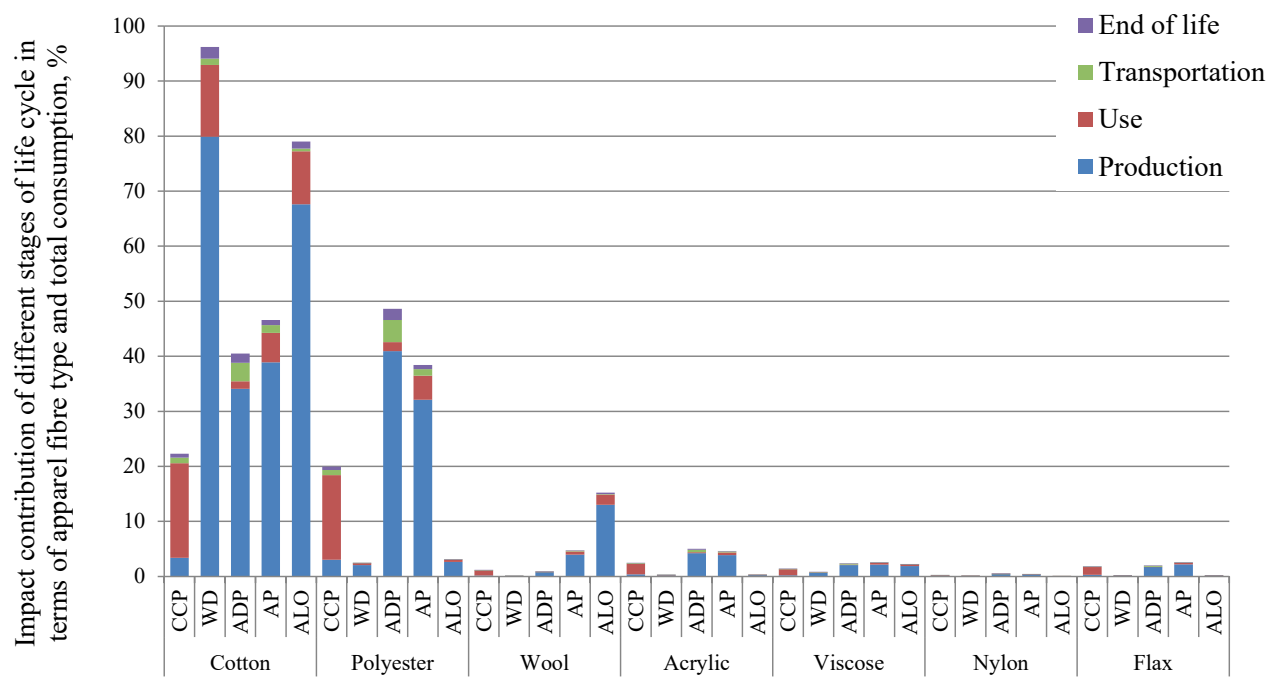

Apparel fibre type

Fig. 11. Impact contribution of different stages of the life cycle. 
TABLE 9. IMPACT CONTRIBUTION OF DIFFERENT FIBRES IN TERMS OF OVERALL CONSUMPTION

\begin{tabular}{|c|c|c|c|c|c|c|}
\hline \multirow{2}{*}{$\begin{array}{l}\text { Fibre used for } \\
\text { apparel } \\
\text { manufacturing }\end{array}$} & \multirow{2}{*}{$\begin{array}{l}\text { Market volume of } \\
\text { fibre for apparel } \\
\text { production, } \%\end{array}$} & \multicolumn{5}{|c|}{ Impact contribution of fibre, $\%$} \\
\hline & & $\mathrm{CCP}$ & WD & $\mathrm{ADP}$ & $\mathrm{AP}$ & ALO \\
\hline Cotton & 53.97 & 45.10 & 96.21 & 40.48 & 46.6 & 79.02 \\
\hline Polyester & 31.79 & 40.39 & 2.48 & 48.62 & 38.43 & 3.10 \\
\hline Wool & 1.57 & 2.39 & 0.06 & 0.90 & 4.76 & 15.21 \\
\hline Acrylic & 3.45 & 5.01 & 0.25 & 5.04 & 4.61 & 0.27 \\
\hline Viscose & 3.40 & 2.85 & 0.78 & 2.43 & 2.6 & 2.23 \\
\hline Nylon & 0.29 & 0.48 & 0.07 & 0.51 & 0.39 & 0.02 \\
\hline Flax & 5.34 & 3.79 & 0.15 & 2.01 & 2.61 & 0.15 \\
\hline
\end{tabular}

\subsubsection{Impact contribution of apparel broad categories}

Impact contributions of apparel broad categories in respect of total consumption are shown in Fig. 12 to Fig. 16. The highest contributors to CCP are cotton knit shirts, cotton woven trousers, polyester woven trousers and polyester knit jackets, which contribute $12.01 \%$, $5.07 \%, 11.30 \%$ and $8.27 \%$ of CCP impact, respectively, as shown in Fig. 12. Cotton apparel is the highest contributor of all impact categories as shown in Fig. 12 to Fig. 16.
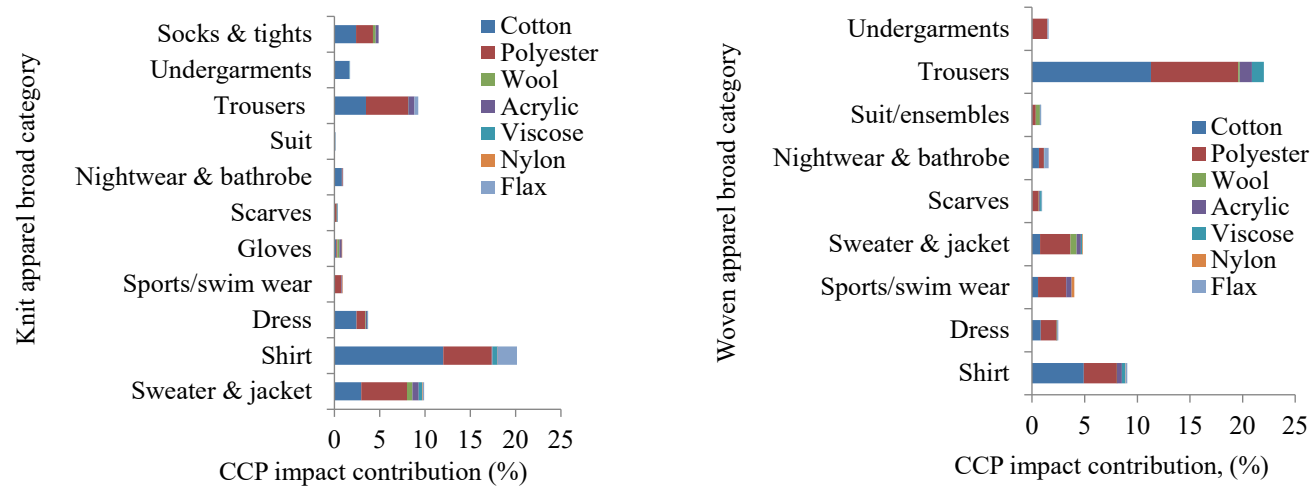

Fig. 12. CCP impact contribution of apparel broad categories based on total market share. 

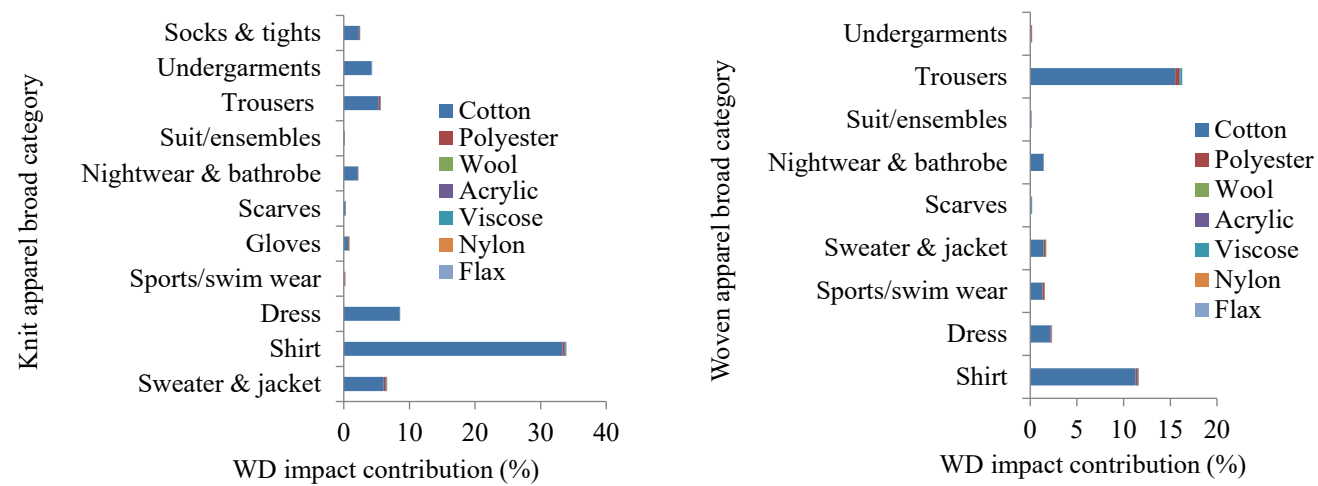

Fig. 13. WD impact contribution of apparel broad categories based on total market share.

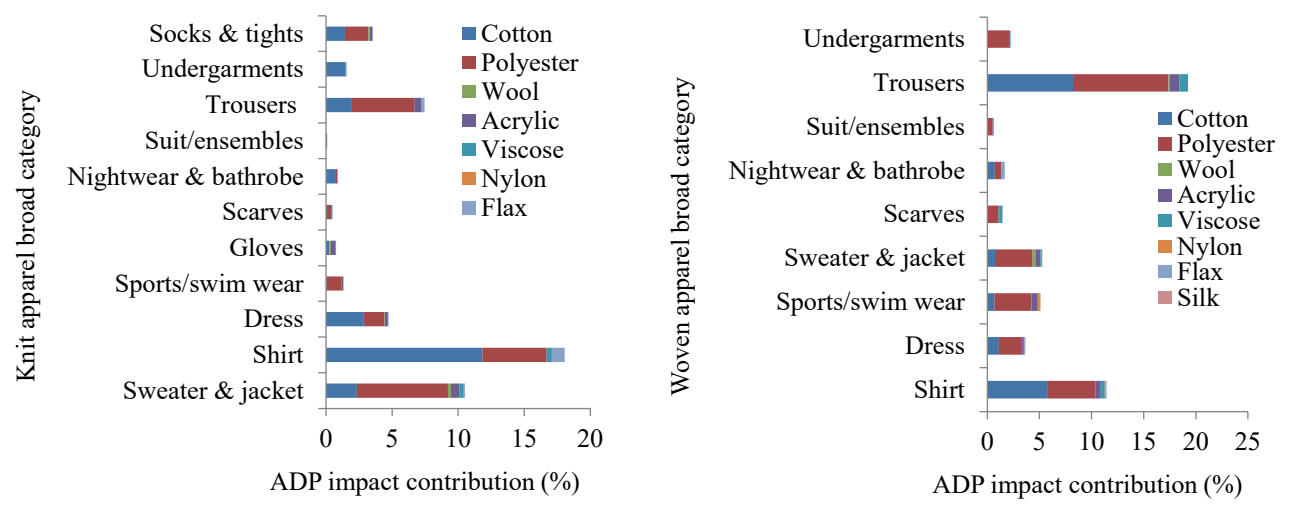

Fig. 14. ADP impact contribution of apparel broad categories based on total market share.
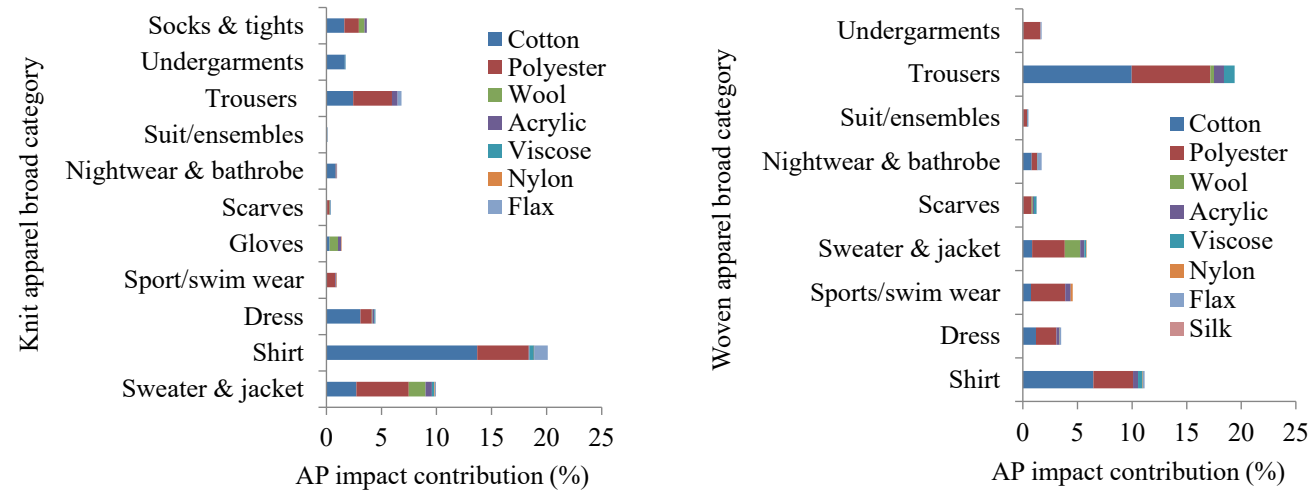

Fig. 15. AP impact contribution of apparel broad categories based on total market share. 

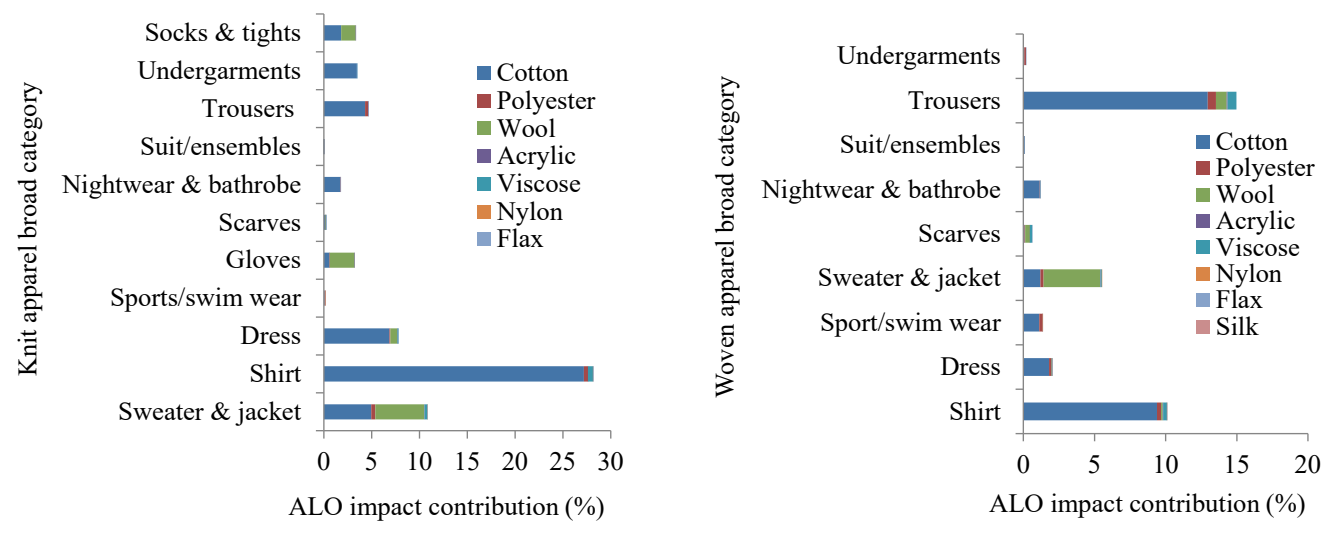

Fig. 16. ALO impact contribution of apparel broad categories based on total market share.

\subsubsection{Impact contribution of sub-stages of life cycle}

The environmental impacts were analysed in terms of the sub-stages or processes involved in the life cycle. The overall results of the analysis are summarized in Fig. 17. Apparel production processes use energy, water and chemicals. The apparel production stage contributes around $58.05 \%, 84.17 \%, 83.52 \%, 85.56 \%$ and $83.03 \%$ of the CCP, ADP, AP, ALO and WD impacts, respectively (Table 8), of which around half the impact of CCP, ADP and AP comes from the energy use for textile processing. Electric energy is required for the textile processing stages (makeup, wet treatment, fabric production and yarn production), which contribute around $25.03 \%$ of CCP, $35.41 \%$ of ADP, and $45.43 \%$ of AP, as shown in Fig. 17.

The minimal impacts of ALO (2.07\%) and WD (1.7\%) come from electrical energy use in textile processing. Among all other textile processes, electricity use in the yarn production process is the highest contributor of CCP (9\%), ADP (12.6\%) and AP (16.07\%), due to the highest energy use during the spinning process of yarn production.

China is the dominant country for apparel production. About $78.4 \%$ of apparel consumed in Australia was imported from China, followed by $10.47 \%$ from Bangladesh, $3.13 \%$ from India, $3.13 \%$ from Indonesia, $3.18 \%$ from Vietnam and $1.69 \%$ from Cambodia (Appendix Table A2) [32]. According to data and statistics from the International Energy Agency, Chinese, Indian and Indonesian electricity comes predominantly from coal-fired power plants: approximately $72 \%, 74 \%$ and $52 \%$, respectively. Electricity production in Vietnam and Cambodia is dominated by hydropower, which is $41 \%$ and $60 \%$, respectively, and electricity production in Bangladesh is dominated by natural gas, which is $82 \%$. To model the overseas production process, an electricity mix model was created using the apparel import share and electricity production mix by electricity source of apparel origin countries (Appendix Table A3 and Table A4). One of the major sources of electricity in the electricity production mix model is a non-renewable energy source, coal. The source of electricity production is one of the important factors driving the environmental impact of the apparel processing stage (makeup, wet treatment, fabric production and yarn production).

Textile raw fibre production, wastewater treatment, chemical use and other resources used in the production process contribute $33.02 \% \mathrm{CCP}, 48.76 \% \mathrm{ADP}, 38.09 \% \mathrm{AP}, 83.49 \%$ ALO and $81.33 \%$ WD. The impact of raw fibre production varies by fibres used for apparel manufacturing. 


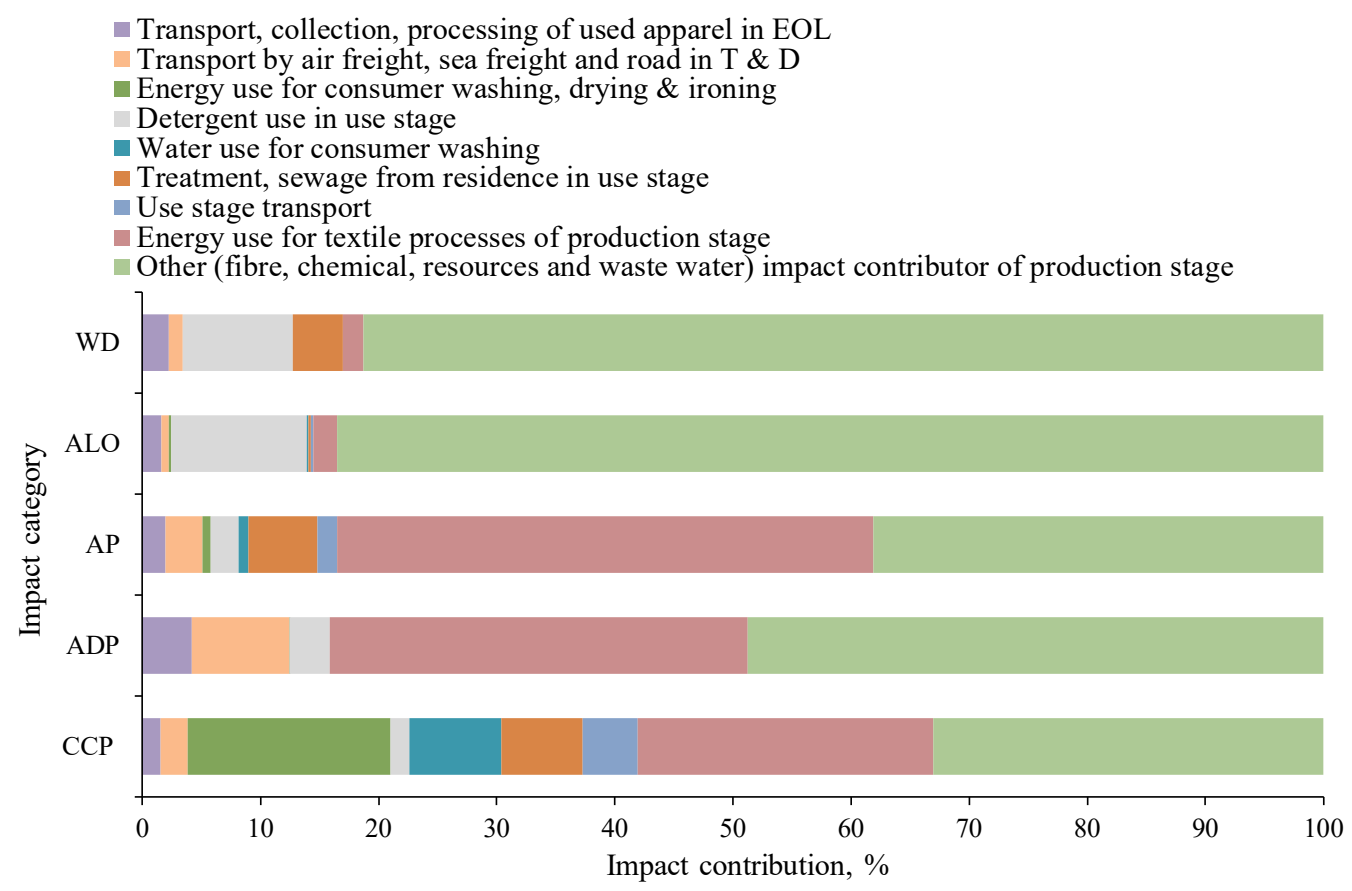

Fig. 17. Impact contribution of energy and other contributors.

The apparel use stage contributes $38.14 \%$ CCP (Table 8), which includes $17.19 \%$ from energy use in consumer washing, drying and ironing, $7.8 \%$ from water use in washing, $6.8 \%$ from treatment of sewage from residences, $4.7 \%$ from passenger cars and $1.57 \%$ from detergent use in washing (Fig. 17). The impact due to international transport during the transportation stage and EOL stages is comparatively insignificant. The transportation stage inside Australia (for consumer transportation) contributes a greater impact than international transportation.

One of the challenges of life cycle assessment related to the supply chain is a breakdown of the environmental impact at the country level. The share of the total impact at country level depends on the production impacts associated with those specific countries which involved individual impact assessment in terms of individual country level. As most of the apparel consumed in Australia was produced overseas, it can be stated that most of the direct impact from apparel production occurs overseas and direct impact from consumer use and EOL stages occurs in Australia. From the estimations of this study, 58.05\% CCP impact directly occurs in producing countries due to raw material processing and apparel production, $2.25 \%$ during international transportation, and $39.7 \%$ directly occurs in Australia due to consumer use and EOL stages in Australia (Table 8). Similarly, $15.81 \%, 7.53 \%, 13.37 \%$ and $13.84 \%$ total WD, ADP, AP and ALO, respectively, directly occurred in Australia due to consumer use and EOL stages (Table 8). 


\section{Discussion}

Environmental impact assessment of apparel consumption in Australia was done in this study by scaling up the impact assessment results of the functional unit to the total consumption. The following points are evident from this impact assessment.

- Environmental impacts of different impact categories per functional unit vary by fibre type and apparel type; the range of average impact is as follows: CCP impact ranges from 28 (for flax apparel) to $67 \mathrm{~kg} \mathrm{CO}_{2} \mathrm{eq}$ (for nylon apparel) (Fig. 5). WD impact ranges from 0.04 (for flax apparel) to $2.5 \mathrm{~m}^{3}$ (for cotton apparel) (Fig. 6). ADP impact ranges from $78 \mathrm{MJ}$ (for flax apparel) to 303 (for nylon apparel) (Fig. 7). AP impact ranges from 0.1 (for flax apparel) to $0.65 \mathrm{~kg} \mathrm{SO}_{2} \mathrm{eq}$ (for wool apparel) (Fig. 8). ALO impact ranges from 0.22 (for flax apparel) to $81 \mathrm{~m}^{2} \mathrm{a}$ (for wool apparel) (Fig. 9).

- Per capita contribution for CCP impact from apparel consumption was $698.07 \mathrm{~kg} \mathrm{CO}_{2}$ eq. Per capita impact of AP, WD, ADP and ALO was estimated as $3.09 \mathrm{~kg} \mathrm{SO}$ eq, $22.89 \mathrm{~m}^{3}, 2878.68 \mathrm{MJ}$ and $119.97 \mathrm{~m}^{2}$ a, respectively. It should be pointed out that the per capita apparel consumption in Australia in 2010 was $13.58 \mathrm{~kg}$; it was $16 \mathrm{~kg}$ per capita in 2015 , which shows an increase by about $18 \%$ over that period. In 2018 it increased by $5 \%$ from 2015 (Fig. 10). It is evident that per capita environmental impact increases with the increase of per capita apparel consumption.

- This study indicated that electricity use in textile production stages (yarn production, fabric production, wet treatment, finishing and apparel production) is one of the main contributors to the impact from the apparel production stage (Fig. 17). The yarn production process was the dominant process for electricity use, as well as a dominant process for impact contribution. Electricity production mix by electricity source of non-renewable energy-coal was the main factor for impact from electricity use. Prioritization of the use of renewable energy or low impact energy sources for textile processing is significant for impact reduction from the production stage. Reduction of production waste is another significant option for impact reduction.

- Around $17.19 \%$ the total CCP impact is contributed by electrical energy use in consumer washing, drying and ironing processes. Of these, $10 \% \mathrm{CCP}$ impact is due to electricity use in the washing process. About $7.8 \% \mathrm{CCP}$ impact is caused by water use in the washing process. Treatment of sewage from residences contributes a high impact to AP (5.82\%) and WD (4.23\%) of all the processes involved in the consumer stage. Detergent use in the washing process contributes a high impact to ADP, ALO and WD (Fig. 17). Changing consumer caring behaviour of apparel can significantly reduce the overall impact from the use stage. The selection of equipment for washing and drying is also important for impact reduction. Educating consumers to better care for their purchased apparel is one key option for reducing overall impact: for example, less frequent washing, washing with a full machine load, use of more efficient washing machines, and avoiding dryer use can be included as better care options. Potential impact reduction can be achieved by increasing apparel service lifetime, as it can be assumed that this will reduce the quantity of apparel purchased by consumers. Increasing service life is dependent on the apparel materials quality and durability, apparel design and consumers changing fashion attitudes.

- About $54 \%$ apparel consumed in Australia was made from cotton, followed by $31 \%$ from polyester fibre. As a result, the majority of the impact contribution of apparel consumption is caused by cotton and polyester fibre. Apparels under the broad 
categories of cotton knit shirts $(18.65 \%)$, cotton woven trousers $(8.41 \%)$, cotton woven shirts $(6.21 \%)$, polyester woven trousers $(4.91 \%)$, polyester knit jackets $(4.69 \%)$, polyester knit shirts $(4.51 \%)$, cotton knit dresses $(4.53 \%)$ and cotton knit jackets $(3.84 \%)$ are high volume and highly consumed products in Australia. Their overall impact contributions are high compared to other apparel due to the high market volume. Prioritization of these products to tackle environmental impact throughout the supply chain can be an option for impact reductions. Reducing the market volume of this apparel or the increasing market volume of flax fibre apparel instead of cotton or polyester fibre apparel can be an option for impact reduction.

\section{BENCHMARKING WITH RELATED STUDIES}

The environmental impact assessment results generated in this study were compared with other published references and reports. It is difficult to compare directly with other studies, because it is not clear what is included or excluded in the system boundary and the source of data used for the studies. Initially, the impact assessment results of the functional unit were compared with available studies. The CCP impact of a cotton shirt (mass $0.28 \mathrm{~kg}$ ) is $8.771 \mathrm{~kg} \mathrm{CO}$ eq in its entire life cycle [12]. Therefore, $31 \mathrm{~kg} \mathrm{CO} 2 \mathrm{eq} / \mathrm{kg}$ for cotton shirts can be calculated using this factor. According to another study on a cotton T-shirt, CCP impact is $40.33 \mathrm{~kg} \mathrm{CO}{ }_{2} \mathrm{eq} / \mathrm{kg}$ for a shirt [10]. CCP impact of the cotton shirt from this study is $28 \mathrm{~kg} \mathrm{CO} 2 \mathrm{eq} / \mathrm{kg}$. According to the JRC Scientific and Technical Report, CCP impact to produce $1 \mathrm{~kg}$ fabric from cotton, polyester, acrylic, nylon, wool and viscose fibre is $22 \mathrm{~kg} \mathrm{CO}$ eq, $28 \mathrm{~kg} \mathrm{CO}$ eq, $37.7 \mathrm{~kg} \mathrm{CO} 2$ eq, $31 \mathrm{~kg} \mathrm{CO}$ eq, $19 \mathrm{~kg} \mathrm{CO}$ eq and $24 \mathrm{~kg} \mathrm{CO}_{2}$ eq, respectively [22]. These values were from raw fibre production through to the fabric production process, but transportation, consumer use and end of life stages were not included in the assessment. An LCA study on wool fibre estimated that the CCP impact to produce 1 $\mathrm{kg}$ wool is $24.9 \mathrm{~kg} \mathrm{CO}$ eq [15]. The study includes only the wool production stage. On average, $63.76 \mathrm{~kg} \mathrm{CO} \mathrm{CO}_{2}$ impact for the entire life cycle of $1 \mathrm{~kg}$ wool apparel has been estimated in this study.

The overall impact of apparel consumption in Australia was compared to the JRC Scientific and Technical Report. Conversion factors of different impact categories have been determined for 1 tonne of clothing consumption from this reference, such as 43.15 tonnes $\mathrm{CO}_{2}$ eq (CCP), 0.18 tonnes $\mathrm{SO}_{2} \mathrm{eq}(\mathrm{AP}), 1499.94 \mathrm{~m}^{3}$ (WD) and $8884.57 \mathrm{~m}^{2}$ a are equivalent for 1 tonne of clothing consumption [22]. The impact values of per tonne apparel consumption calculated in this study correspond with these conversion factors.

According to one study around $45 \%$ of global apparel production and consumption-related carbon emission occurred in the region where clothing is consumed or used [63]. The annual CCP impact per capita for apparel consumption is $698 \mathrm{~kg} \mathrm{CO}_{2} \mathrm{eq}$, of which $39.7 \%$ (277 kg CO 2 eq) occurred in Australia locally due to apparel use $(38.14 \%)$ and end of life $(1.56 \%)$, which is close to the global average emissions that occurred in the region due to clothing use.

\section{CONClusion}

To assess the environmental impact of apparel consumption in Australia, a lifecycle assessment-based approach was applied to 11 selected apparel broad categories. These selected categories were considered as representative of apparel consumed in Australia. The assessment results represent a complete overview of the environmental impact of apparel 
consumption in Australia. The overall results of this study may serve as a baseline for impact reduction from the apparel sector as well as for setting targets. There are some opportunities for environmental impact reduction identified across the life cycle of apparel. Selection of fibres for apparel manufacturing is important for impact reduction. For example, apparel consumed in Australia is dominated by cotton and polyester fibre. Therefore, most of the impacts are from cotton and polyester apparel. Increasing market consumption of flax fibre apparel instead of cotton and polyester fibre apparel may be an alternative for impact reduction. This study was based on apparel produced from a single fibre. Introducing mixed fibre in different ratios may be an option for impact reduction. Prioritization of the use of renewable energy source for textile processing and consumer use stage activities are significant for impact reduction.

On average, the apparel production stage contributes the highest impact of all impact categories, followed by the consumer use stage. Nevertheless, it is difficult to address which one is more important for increasing sustainability throughout the supply chain, production or consumer use stages. They are inter-related. Apparel production increases with an increase in consumer demand. Increased consumer demand is mainly due to changing fashion attitudes and affordable fashion. Increased consumer demand also results in increased apparel disposal. Apparel that is disposed of after single use has a high impact compared to apparel which is disposed of after 50 uses. However, in the case of single use, the apparel needs to be replaced frequently, which involves more production, more raw materials, more chemicals, more energy use, and consequently more environmental impact. As a consequence, consumer's buying and disposal attitudes are much more important. About $95 \%$ of the disposed-of clothing by Australians is recyclable and reusable. Therefore, extending apparel lifetime by reusing or recycling and buying less is the key factor for reducing overall impact significantly. The consumer can be encouraged to buy less quantity but higher quality apparel, which will lead to less per capita demand, instead of buying more affordable apparel but in large quantities. The consumer also needs to be educated to minimise the disposal of used apparel by extending apparel lifetime.

Every model has its own uncertainties and limitations. A complete life cycle assessment study of any supply chain is difficult and challenging due to the lack of available, verified industry datasets. Textile product manufacturing involves many processes, utilities, resources and chemicals. The exact amount and chemical formula of these input parameters for LCA are not very publicly accessible. Different dyes are used for textile coloration. Textile dye production databases are not available in the Ecoinvent v3 dataset and literature. All the input parameters have some specific impact on the environment. In this case, similar types of chemical datasets of Ecoinvent v3 were used according to their chemical name and formula. Another limitation of this study is the use of single fibre fabric. Fibre blends for apparel production are very common, but due to the complexity of fibre blending and data availability, only single fibre apparel was considered in this study.

Textile product inventories in the Ecoinvent v3 dataset are very limited. Development of a central textile database is important for textile product life cycle assessment. Furthermore, textile raw fibre production datasets from different geographical locations are required for a complete LCA model of the supply chain. This study involved several origin countries for raw material and apparel production. The Ecoinvent v3 datasets may sometimes not be specific for other regions. The impact ratio varies according to geographic locations of raw material and textile production processes. It is also difficult to modify the existing datasets based on specific geographic regions. Specific geographic region-based primary data can improve the accuracy of impact estimation. In this study, the average global dataset from Ecoinvent v3 was used for most of the processes involved in the production stage. There are 
some other limitations in this study: for example, different production technologies were not taken into account, and only typical textile processes were used from relevant references. Due to the lack of information on apparel end of life, assumptions have been made to allocate discarded apparel to different end of life routes. Another assumption has been made for travel distance by road transport. Use of these assumptions can be acknowledged as limitations of this study.

\section{ACKNOWLEDGEMENT}

The study has been supported by the Australian Government Research Training Program (RTP) and Research Stipend Scholarship.

\section{REFERENCES}

[1] Kerr J., Landry J. Pulse of the fashion industry. Global Fashion Agenda, Copenhagen, Denmark; The Boston Consulting Group: Boston, MA, USA, 2017.

[2] Boström M., Micheletti M. Introducing the sustainability challenge of textiles and clothing. Journal of Consumer Policy 2016:39:367-375. https://doi.org/10.1007/s10603-016-9336-6

[3] Shen B., Li Q., Dong C., Perry P. Sustainability Issues in Textile and Apparel Supply Chains. Sustainability 2017:9(9):1592. https://doi.org/10.3390/su9091592

[4] Fletcher K. Sustainable fashion and textiles: design journeys. $2^{\text {nd }}$ Ed., London: Routledge, 2013.

[5] Subic A., Shabani B., Hedayati M., Crossin E. Capability Framework for Sustainable Manufacturing of Sports Apparel and Footwear. Sustainability 2012:4(9):2127-2145. https://doi.org/10.3390/su4092127

[6] Subic A., Shabani B., Hedayati M., and Crossin E. Performance Analysis of the Capability Assessment Tool for Sustainable Manufacturing. Sustainability 2013: 5. doi: https://doi.org/10.3390/su5083543

[7] Allwood J. M., Laursen S. E., de Rodriguez C. M., Bocken N. M. Well dressed? The present and future sustainability of clothing and textiles in the United Kingdom. University of Cambridge Institute for Manufacturing, Great Britain, 2015 [Online]. [Accessed 30.09.2020]. Available: https://www.ifm.eng.cam.ac.uk/insights/sustainability/welldressed/

[8] Muthu S. S. Assessing the environmental impact of textiles and the clothing supply chain. $1^{\text {st }}$ Ed., Woodhead Publishing, 2014.

[9] Kalliala E. M., Nousiainen P. Environmental profile of cotton and polyester-cotton fabrics. Autex Research Journal 1999:1:8-20. [Online]. [Accessed 30.09.2020]. Available: https:/tutcris.tut.fi/portal/en/publications/environmentalprofile-of-cotton-and-polyester-cotton-fabrics(4e00cf80-d563-4fba-8709-13bfa0f24287).html

[10] Zhang Y., Liu X., Xiao R., Yuan Z. Life cycle assessment of cotton T-shirts in China. The International Journal of Life Cycle Assessment 2015:20:994-1004. https://doi.org/10.1007/s11367-015-0889-4

[11] Yuan Z.-W., Zhu Y.-N., Shi J.-K., Liu X., Huang L. Life-cycle assessment of continuous pad-dyeing technology for cotton fabrics. The International Journal of Life Cycle Assessment 2013:18:659-672. https://doi.org/10.1007/s11367-012-0470-3.

[12] Wang C., Wang L., Liu X., Du C., Ding D., Jia J., Wu G. Carbon footprint of textile throughout its life cycle: a case study of Chinese cotton shirts. Journal of Cleaner Production 2015:108:464-475. https://doi.org/10.1016/j.jclepro.2015.05.127

[13] Baydar G., Ciliz N., Mammadov A. Life cycle assessment of cotton textile products in Turkey. Resources, Conservation and Recycling 2015:104:213-223. https://doi.org/10.1016/j.resconrec.2015.08.007

[14] Walser T., Demou E., Lang D. J., and Hellweg S. Prospective Environmental Life Cycle Assessment of Nanosilver T-Shirts. Environmental Science \& Technology 2011:45:4570-4578. https://doi.org/10.1021/es2001248

[15] Henry B. K., Russell S. J., Ledgard S. F., Gollnow S., Wiedemann S. G., Nebel B., Masle D., Swan P. LCA of Wool Textiles and Clothing. Handbook of Life Cycle Assessment (LCA) of Textiles and Clothing. 2015:217-254. https://doi.org/10.1016/B978-0-08-100169-1.00010-1

[16] Russell I. M. Sustainable Wool Production and Processing. Sustainable Textiles Life Cycle and Environmental Impact 2009:63-87. https://doi.org/10.1533/9781845696948.1.63

[17] Bevilacqua M., Ciarapica F., Giacchetta G., Marchetti B. A carbon footprint analysis in the textile supply chain. International Journal of Sustainable Engineering 2011:4(1):24-36. https://doi.org/10.1080/19397038.2010.502582

[18] Kadnikova O.., Altynbayeva G., Kuzmin S., Aidarkhanov A., Toretayev M., Khabdullina Z. Ecological Feasibility of Applying Technology in Recycling Garment and Knitwear Production. Environmental and Climate Technologies 2019:23:291-309. https://doi.org/10.2478/rtuect-2019-0069 
[19] Sandin G., Peters G. M. Environmental impact of textile reuse and recycling-A review. Journal of Cleaner Production 2018:184:353-365. https://doi.org/10.1016/j.jclepro.2018.02.266

[20] Zamani B. Carbon footprint and energy use of textile recycling techniques. Master of Science. Department of Chemical and Biological Engineering. Chalmers University of Technology. Göteborg, Sweden. 2011. [Online]. [Accessed 30.09.2020]. Available: http://publications.lib.chalmers.se/records/fulltext/146872.pdf

[21] Farrant L., Olsen S. I., Wangel A. Environmental benefits from reusing clothes. The International Journal of Life Cycle Assessment 2010:15:726-736. https://doi.org/10.1007/s11367-010-0197-y

[22] Beton A., Dias D., Farrant L., Gibon T., Le Guern Y., Desaxce M., Perwueltz A., Boufateh I., Wolf O., Kougoulis I. S., Cordella M., Dodd N. P. Environmental improvement potential of textiles (IMPRO-Textiles). European Commission, 2014. [Online]. [Accessed 30.09.2020]. Available: https://ec.europa.eu/jrc/en/publication/eurscientific-and-technical-research-reports/environmental-improvement-potential-textiles-impro-textiles

[23] Thomas B., Fishwick M., Joyce J., van Santen A. A Carbon Footprint for UK Clothing and Opportunities for Savings. Banbury, UK: WRAP, 2012.

[24] Moazzem S., Crossin E., Daver F., Wang L. Baseline Scenario of Carbon Footprint of Polyester T-Shirt. Journal of Fiber Bioengineering and Informatics 2018:11:1-14. https://doi.org/10.3993/jfbim00262

[25] Carmichael A. Man-Made Fibres Continue to Grow. 2016. [Online]. [Accessed 01.07.2018]. Available: http://www.textileworld.com/textile-world/fiber-world/2015/02/man-made-fibers-continue-to-grow/

[26] Reinout H. Ecodesign - Carbon Footprint - Life Cycle Assessment - Life Cycle Sustainability Analysis. A Flexible Framework for a Continuum of Tools. Environmental and Climate Technologies 2010:4:42-46. https://doi.org/10.2478/v10145-010-0016-5

[27] Moazzem S., Wang L., Daver F., and Crossin E. Environmental impact of discarded apparel landfilling and recycling. Resources, Conservation and Recycling 166:105338. https://doi.org/10.1016/j.resconrec.2020.105338

[28] Kubule A., Klavenieks K., Vesere R., and Blumberga D. Towards Efficient Waste Management in Latvia: An Empirical Assessment of Waste Composition. Environmental and Climate Technologies 2019:23:114-130. https://doi.org/10.2478/rtuect-2019-0059

[29] Lucchetti M. G., Paolotti L., Rocchi L., and Boggia A. The Role of Environmental Evaluation within Circular Economy: An Application of Life Cycle Assessment (LCA) Method in the Detergents Sector. Environmental and Climate Technologies 2019:23:238-257. https://doi.org/10.2478/rtuect-2019-0066

[30] Kubule A., Blumberga D. Sustainability Analysis of Manufacturing Industry. Environmental and Climate Technologies 2019:23:159-169. https://doi.org/10.2478/rtuect-2019-0086

[31] IBISWorld. IBISWorld Industry Report C1351a, Men's and Boys' Wear Manufacturing in Australia. 2016.

[32] United Nations Department of Economic and Social Affairs, UN Comtrade Database. [Online]. [Accessed: 15.04.2020]. Available: https://comtrade.un.org/data/

[33] Australian Customs and Border Protection Service. Commonly Imported Goods. [Online]. [Accessed 10.03.2020]. Available: https://www.abf.gov.au/importing-exporting-and-manufacturing/importing/how-to-import/requirements

[34] Wernet G., Bauer C., Steubing B., Reinhard J., Moreno-Ruiz E., Weidema B. The ecoinvent database version 3 (part I): overview and methodology. The International Journal of Life Cycle Assessment 2016:21:1218-1230. https://doi.org/10.1007/s11367-016-1087-8

[35] Dissanayake N. P., Summerscales J., Grove S., Singh M. Energy use in the production of flax fiber for the reinforcement of composites. Journal of Natural Fibers 2009:6:331-346. https://doi.org/10.1080/15440470903345784

[36] CML. CML-IA Characterisation Factors. Version 4.4, 2015. [Online]. [Accessed 15.06.2016]. Available: https:/www.universiteitleiden.nl/en/research/research-output/science/cml-ia-characterisation-factors

[37] Goedkoop M., Heijungs R., Huijbregts M., De Schryver A., Struijs J., Van Zelm R. A life cycle impact assessment method which comprises harmonised category indicators at the midpoint and the endpoint level. The Hague, Ministry of VROM, ReCiPe, 2009.

[38] Saxce de M., Pesnel S., Perwuelz A. LCA of bed sheets-some relevant parameters for lifetime assessment. Journal of Cleaner Production 2012:37:221-228. https://doi.org/10.1016/j.jclepro.2012.07.012

[39] OECD.stat. OECD, Greenhouse gas emissions 2019. [Online]. [Accessed 15.04.2020]. Available: https://stats.oecd.org/Index.aspx?DataSetCode=AIR_GHG\#

[40] Population Australia. Australia Population 2019. [Online]. [Accessed 10.04.2020]. Available: http://www.population.net.au/

[41] Australian Bureau of Statistics. 4602.2 - Household Water, Energy Use and Conservation, Victoria, Oct 2009. [Online]. [Accessed: 10.04.2020]. Available:

https:/www.abs.gov.au/ausstats/abs@.nsf/0/7E391A69F25A1F30CA25774A0013BF89?opendocument

[42] Australian Institute of Family Studies. Population and households. [Online]. [Accessed 10.04.2020]. Available: https://aifs.gov.au/facts-and-figures/population-and-households

[43] Bengtsson J., Howard N. A life cycle impact assessment method, part 2: Normalization. Engadine, NSW: Building Products Innovation Council, 2010.

[44] The Australian National Life Cycle Inventory Database (AusLCI). The Australian Life Cycle Assessment Society (ALCAS). 2015. [Online]. [Accessed 15.04.2020]. Available: http://auslci.com.au/ 
[45] Weidema B. P., Wesnaes M. S. Data quality management for life cycle inventories — an example of using data quality indicators. Journal of cleaner production 1996:4(3-4):167-174. https://doi.org/10.1016/S0959-6526(96)00043-1

[46] Weidema B. P., Bauer C., Hischier R., Mutel C., Nemecek T., Reinhard J., Vadenbo C.O., Wernet G. Overview and methodology. Data quality guideline for the ecoinvent database version 3. Ecoinvent Report 1(v3). St. Gallen: The ecoinvent Centre, Swiss Centre for Life Cycle Inventories, 2013. [Online]. [Accessed 10.03.2020]. Available: https:/www.ecoinvent.org/files/dataqualityguideline_ecoinvent_3_20130506.pdf

[47] The Fiber Year Consulting. The Fiber Year 2019: World Survey on Textiles \& Nonwovens. 2019. The Fiber Year $\mathrm{GmbH}$, Switzerland. Available: https://www.thefiberyear.com/fileadmin/pdf/TOC2019.pdf

[48] Laursen S. E., Hansen J., Bagh J., Jensen O., and Werther I. Environmental Assessment of Textiles. Life Cycle Screening of Textiles Containing Cotton, Wool, Viscose, Polyester or Acrylic Fibres. Miljoprojekt 1997:369. https://doi.org/10.13140/RG.2.1.2584.1124

[49] American Fiber Manufacturers Association. Resource and Environmental Profile Analysis of a Manufactured Apparel Product: Woman's Knit Polyester Blouse. Washington, DC, 1993.

[50] Schönberger H., Schäfer T. Best available techniques in textile industry. ed. vol. Research Report 200 94 329. Berlin: Federal Environmental Agency. 2003. [Online]. [Accessed 10.03.2020]. Available: https:/www.umweltbundesamt.de/sites/default/files/medien/publikation/long/2274.pdf

[51] Yacout D. M., El-Kawi M. A., Hassouna M. Cradle to gate environmental impact assessment of acrylic fiber manufacturing. The International Journal of Life Cycle Assessment 2016:21:326-336. https://doi.org/10.1007/s11367-015-1023-3

[52] Dissanayake N., Summerscales J., Grove S., and Singh M. Quantitative life cycle analysis for flax fibers. In Proceedings of the $17^{\text {th }}$ International Conference for Composite Materials (ICCM-17), CD-ROM F, 2009.

[53] Moazzem S., Daver F., Crossin E., Wang L. Assessing environmental impact of textile supply chain using life cycle assessment methodology. The Journal of The Textile Institute 2018:109:1574-1585. https://doi.org/10.1080/00405000.2018.1434113

[54] Australian Bureau of Statistics. Environmental Issues: Waste Management, Transport and Motor Vehicle Usage, Mar 2012. [Online]. [Accessed 09.06.2017]. Available: https://www.abs.gov.au/ausstats/abs@.nsf/mf/4602.0.55.002

[55] Grace P., Gane M., and Garcia F. Life Cycle Assessment of a 100\% Australian Cotton T-shirt. 2009. Institute for Sustainable Resources, Queensland University of Technology, QLD.

[56] Australian Government Department of the Environment and Energy. Energy rating data for household appliances labelled products, clothes washers. [Online]. [Accessed 10.05.2016]. Available: https://data.gov.au/dataset/energyrating-for-household-appliances

[57] Aware. How much laundry detergent should I use? Aware Environmental creating a greener footprint, 2017. [Accessed 10.06.2017]. Available: https://www.awareenvironmental.com.au/blog/blog-post-title-one-nfhel

[58] EPA Victoria and City West Water. LCA of Clothes Washing Options for City West Water's Residential Customers Life Cycle Assessment. Final Technical Report. 2010.

[59] Drycleaning Institute of Australia. International fair claims guide for consumer textile products. 2018. [Online]. [Accessed: 16.12.2020] Available: https:/www.drycleanersweb.com.au/sites/default/files/usercontent/resources/file/171215_fair_claims_guide_0.pdf

[60] Caulfield K. Sources of textile waste in Australia. Technical Textiles \& Nonwoven Association, 2018. [Online]. [Accessed 12.01.2019] Available: http://www.ttna.com.au

[61] Collins M., Aumônier S. Streamlined life cycle assessment of two Marks \& Spencer plc apparel products. Environmental Resources Management, Oxford, 2002. [Online]. [Accessed 15.04.2020]. Available: https://researchingsustainability.files.wordpress.com/2012/01/streamlined-lca-of-2-marks-spencer-pls-apparelproducts.pdf

[62] Sea-Distance.org. Sea Distances / Port Distances. Online tool for calculation distances between sea ports. 2017. [Online]. [Accessed 12.10.2016]. Available: https://sea-distances.org

[63] Carbon Trust. International Carbon Flows - Clothing. 2011. Carbon Trust, UK. 


\section{APPENDIX}

\section{Apparel Consumption in Australia}

TABle A1. Estimated Market Consumption of APPARELS IN Terms of APPARElS AND Fibre TYPE (IN KG) [A1] (NOTE: REFERENCES FOR THIS APPENDIX ARE LISTED IN TABLE A10.)

\begin{tabular}{|c|c|c|c|c|c|c|c|c|c|c|c|c|c|}
\hline 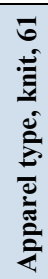 & 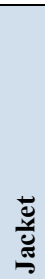 & ॠ & $\frac{\tilde{b}}{\square}$ & ह & $\begin{array}{l}\frac{v}{0} \\
\frac{\partial}{U}\end{array}$ & 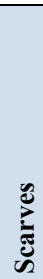 & 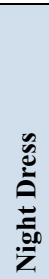 & $\ddot{\Xi}$ & 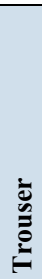 & 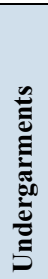 & 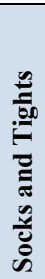 & 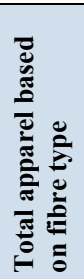 & 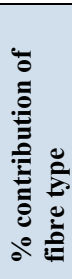 \\
\hline 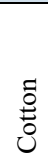 & 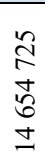 & 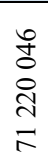 & 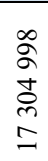 & 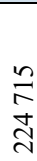 & $\begin{array}{l}\text { ơ } \\
\text { o } \\
\text { in } \\
-\end{array}$ & $\begin{array}{l}\stackrel{8}{\circ} \\
\frac{\partial}{\sigma}\end{array}$ & 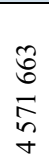 & 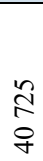 & \begin{tabular}{l} 
\\
\multirow{2}{*}{} \\
$\infty$ \\
$n$ \\
$=$ \\
$=$
\end{tabular} & $\begin{array}{l}\infty \\
m \\
\infty \\
\infty \\
\infty\end{array}$ & $\begin{array}{l}\frac{m}{\alpha} \\
\hat{q} \\
0 \\
0\end{array}$ & $\begin{array}{l}\text { के } \\
\text { on } \\
\hat{\alpha} \\
\hat{o} \\
\text { ñ }\end{array}$ & $\begin{array}{l} \\
\infty \\
i n \\
m\end{array}$ \\
\hline 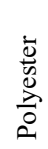 & 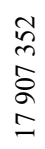 & $\begin{array}{l}\text { ה } \\
\text { הે } \\
\text { I }\end{array}$ & 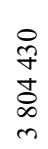 & $\begin{array}{l}\frac{\infty}{2} \\
\frac{m}{\sigma} \\
\sim\end{array}$ & $\begin{array}{l}\bar{m} \\
\stackrel{m}{\sigma}\end{array}$ & 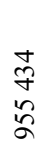 & 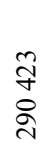 & 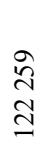 & $\begin{array}{l}\infty \\
\infty \\
\infty \\
\infty \\
\sigma \\
= \\
=\end{array}$ & & 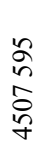 & 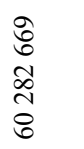 & $\begin{array}{l}\stackrel{2}{\imath} \\
i n\end{array}$ \\
\hline $\begin{array}{l}\overline{8} \\
\overline{8}\end{array}$ & 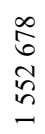 & & $\begin{array}{l}n \\
\infty \\
\infty \\
\tilde{n}\end{array}$ & & \begin{tabular}{l} 
Iิ \\
\multirow{2}{0}{}
\end{tabular} & $\begin{array}{l}\underset{\infty}{\infty} \\
\infty \\
\infty\end{array}$ & & & $\begin{array}{l}\text { aे } \\
\text { in } \\
\text { f }\end{array}$ & & 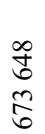 & $\begin{array}{l}\infty \\
\stackrel{\infty}{n} \\
\hat{N} \\
\text { n }\end{array}$ & $\begin{array}{l}0 \\
\infty \\
0\end{array}$ \\
\hline 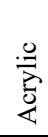 & $\begin{array}{l}\tilde{N} \\
\infty \\
\infty \\
\tilde{N}\end{array}$ & $\begin{array}{l}n \\
\hat{\sigma} \\
\infty \\
\infty \\
\sigma\end{array}$ & $\begin{array}{l}\bar{n} \\
\vec{\sigma} \\
\vec{\sigma}\end{array}$ & $\begin{array}{l}\stackrel{0}{0} \\
\text { in } \\
\text { nn }\end{array}$ & 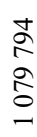 & $\begin{array}{l}\text { ป్ర } \\
\text { ¿ } \\
\text { I }\end{array}$ & & 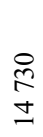 & $\begin{array}{l}\stackrel{\vartheta}{\forall} \\
\infty \\
\stackrel{\infty}{+} \\
-\end{array}$ & & $\frac{\infty}{2}$ & $\begin{array}{l}\vec{\infty} \\
\stackrel{\infty}{+} \\
\stackrel{v}{n} \\
0\end{array}$ & $\vec{F}$ \\
\hline $\begin{array}{l}0 \\
0 \\
0 \\
0 \\
0 \\
\vdots\end{array}$ & $\begin{array}{l}\stackrel{\infty}{*} \\
\underset{\sigma}{\sigma}\end{array}$ & 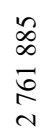 & $\begin{array}{l}\text { 三 } \\
\underset{J}{J}\end{array}$ & & & $\begin{array}{l}\stackrel{a}{0} \\
\stackrel{\Xi}{\Xi}\end{array}$ & & $\stackrel{\mathcal{F}}{q}$ & & $\begin{array}{l}\bar{F} \\
\tilde{n} \\
\dot{0}\end{array}$ & & $\begin{array}{l}0 \\
\text { 市 } \\
\stackrel{2}{2} \\
\text { in }\end{array}$ & $\stackrel{\cap}{n}$ \\
\hline$\frac{\text { o }}{\bar{\lambda}}$ & $\begin{array}{l}\infty \\
\infty \\
\infty \\
\infty \\
\sim\end{array}$ & $\begin{array}{l}\infty \\
\stackrel{N}{0} \\
\infty \\
\infty\end{array}$ & & $\begin{array}{l}\hat{\imath} \\
n \\
n \\
m\end{array}$ & $\underset{\substack{\infty \\
\sim}}{\infty}$ & & & & & & & $\begin{array}{l}\hat{a} \\
\hat{n} \\
\hat{n}\end{array}$ & $\stackrel{0}{0}$ \\
\hline$\frac{\underset{\Xi}{\leftrightarrows}}{\frac{夭}{I}}$ & $\begin{array}{l}3 \\
+ \\
0 \\
0 \\
\infty\end{array}$ & 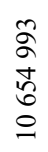 & 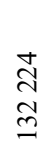 & & & $\begin{array}{l}\tilde{\gamma} \\
\stackrel{\alpha}{\alpha}\end{array}$ & $\begin{array}{l}8 \\
\& \\
\& \\
\not{y}\end{array}$ & $\underset{\infty}{\hat{\sigma}}$ & 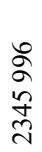 & $\begin{array}{l}\text { m } \\
\text { }\end{array}$ & & $\begin{array}{l}\stackrel{0}{n} \\
\tilde{m} \\
\text { fo } \\
\text { I }\end{array}$ & $\begin{array}{l}0 \\
\infty \\
\end{array}$ \\
\hline 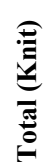 & & & & & & & & & & & & 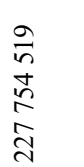 & \\
\hline
\end{tabular}




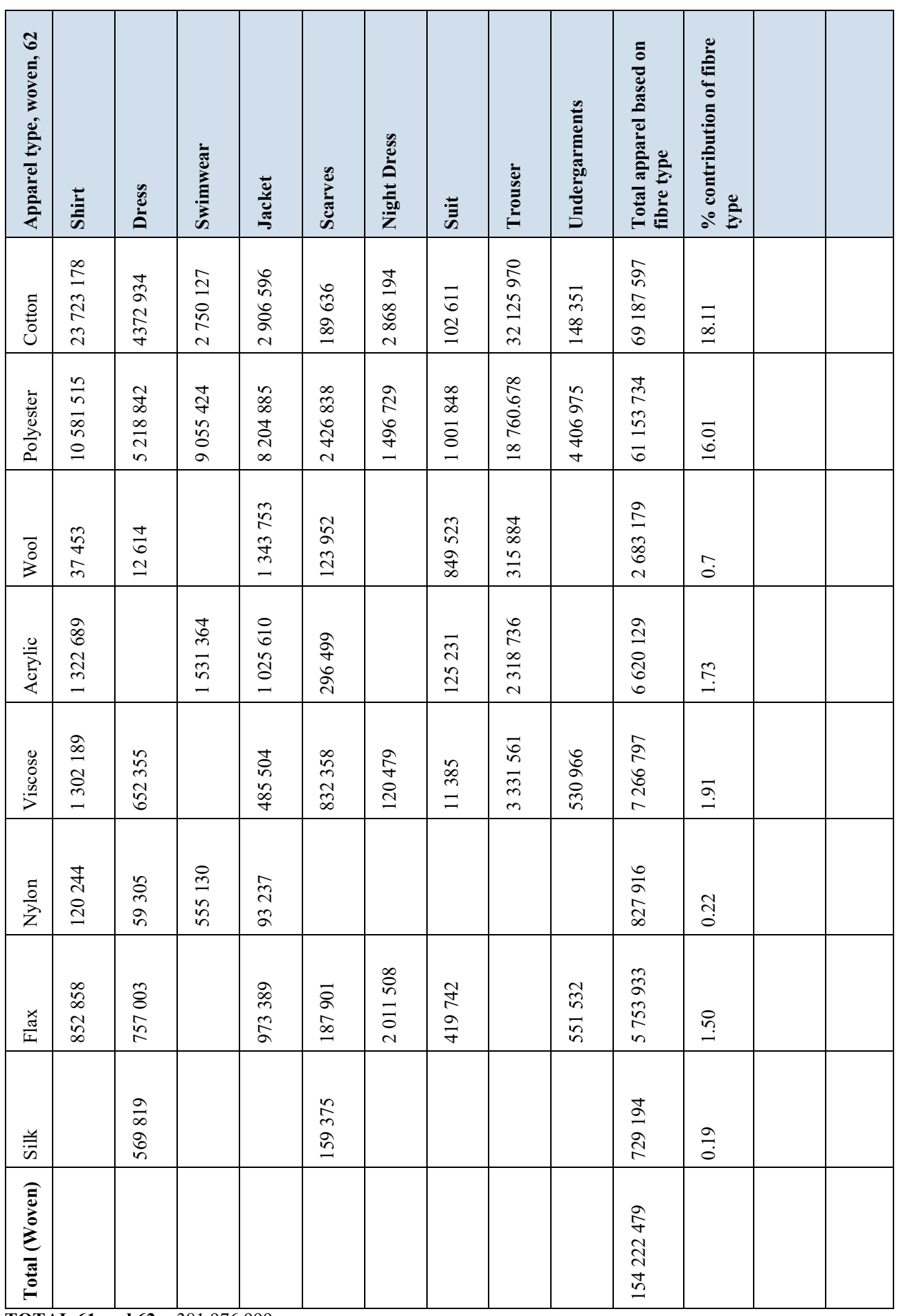

TOTAL 61 and $62=381976999$ 


\section{APPAREL IMPORT SHARE BY COUNTRY OF ORIGIN}

Table A2 represents apparel import share percentage by country of origin. A cut of approach of $1.5 \%$ was applied to estimate the apparel import share of six biggest apparel origin countries.

TABle A2. Apparel Import Share Percentage by COUnTRy of Origin [A1]

\begin{tabular}{lll}
\hline Origin country & Cut off \% $\mathbf{1 . 5}$ & Import share, \\
\hline China & $68.72 \%$ & 78.40 \\
Bangladesh & $9.18 \%$ & 10.47 \\
Vietnam & $2.79 \%$ & 3.18 \\
Indonesia & $2.74 \%$ & 3.13 \\
India & $2.74 \%$ & 3.13 \\
Cambodia & $1.48 \%$ & 1.69 \\
\hline
\end{tabular}

\section{Electricity MiX Models}

All the production processes use electricity. Electricity mix dataset for the main apparel producing countries was created based on the apparel import share of six biggest origin countries; China, Bangladesh, Vietnam, India, Indonesia and Cambodia. Electricity production database for Bangladesh, Cambodia and Vietnam is not available in Ecoinvent v3; therefore, electricity mix database of these countries was created using the statistics of International Energy Agency [A2].

Table A3 and Table A4 show the Electricity production mix (\%) by import country and share of the electricity mix by country of origin with data set, respectively.

Table A3. Electricity Production Mix, \%, By Electricity Production Source [A3] for BANGLADESH, VIETNAM AND CAMBODIA [A2]

\begin{tabular}{|c|c|c|c|c|}
\hline Production from & Bangladesh & Vietnam & Cambodia & Ecoinvent dataset [A4] \\
\hline Coal & 1.97 & 24.53 & 28.21 & $\begin{array}{l}\text { Electricity, high voltage }\{\mathrm{IN}\} \mathrm{W} \mid \\
\text { electricity production, hard coal Alloc } \\
\text { Def, U }\end{array}$ \\
\hline Oil & 14.70 & 0.32 & 10.69 & $\begin{array}{l}\text { Electricity, high voltage }\{\mathrm{IN}\} \mid \text { electricity } \\
\text { production, oil | Alloc Def, } \mathrm{U}\end{array}$ \\
\hline Gas & 82.01 & 33.50 & & $\begin{array}{l}\text { Electricity, high voltage }\{\mathrm{IN}\} \mid \text { electricity } \\
\text { production, natural gas, at conventional } \\
\text { power plant } \mid \text { Alloc Def, } U\end{array}$ \\
\hline Biofuel & 0.26 & 0.04 & 0.46 & $\begin{array}{l}\text { Electricity, low voltage }\{\mathrm{IN}\} \mid \text { electricity } \\
\text { production, photovoltaic, } 3 \mathrm{kWp} \text { facade } \\
\text { installation, multi-Si, laminated }\end{array}$ \\
\hline Hydro & 1.05 & 41.55 & 60.54 & $\begin{array}{l}\text { Electricity, high voltage }\{\mathrm{IN}\} \mid \text { electricity } \\
\text { production, hydro, reservoir, alpine } \\
\text { region | Alloc Def, } U\end{array}$ \\
\hline Wind & 0.01 & 0.06 & & $\begin{array}{l}\text { Electricity, high voltage }\{\mathrm{IN}\} \mid \text { electricity } \\
\text { production, wind, }<1 \mathrm{MW} \text { turbine, } \\
\text { onshore } \mid \text { Alloc Def, } \mathrm{U}\end{array}$ \\
\hline Distribution loss & $12.4 \%$ & $7.1 \%$ & $15.5 \%$ & \\
\hline
\end{tabular}


TABLE A4. SHARE OF THE ELECTRICITY MIX BY COUNTRY OF ORIGIN

\begin{tabular}{|c|c|c|}
\hline Origin country & $\begin{array}{l}\text { Share of electricity mix (as per } \\
\text { import share of apparel origin } \\
\text { country) }\end{array}$ & Ecoinvent Dataset [A4] \\
\hline China & 78.40 & $\begin{array}{l}\text { Electricity, medium voltage }\{\mathrm{CN}\} \mid \text { market for } \\
\mid \text { Alloc Def, } U\end{array}$ \\
\hline Bangladesh & 10.47 & $\begin{array}{l}\text { Electricity mix model for Bangladesh grid } \\
\text { (electricity mix data for the year of } 2015 \text { was } \\
\text { collected from International energy agency as } \\
\text { stated in Table A3) }\end{array}$ \\
\hline Vietnam & 3.18 & $\begin{array}{l}\text { Electricity mix for Vietnam grid (electricity } \\
\text { mix data for the year of } 2015 \text { was collected } \\
\text { from International energy agency as stated in } \\
\text { Table A3) }\end{array}$ \\
\hline Indonesia & 3.13 & $\begin{array}{l}\text { Electricity, medium voltage }\{\mathrm{ID}\} \mid \text { market for } \mid \\
\text { Alloc Def, } U\end{array}$ \\
\hline India & 3.13 & $\begin{array}{l}\text { Electricity, medium voltage }\{\mathrm{IN}\} \mid \text { market for } \mid \\
\text { Alloc Def, } U\end{array}$ \\
\hline Cambodia & 1.69 & $\begin{array}{l}\text { Electricity mix model for Cambodia grid } \\
\text { (electricity mix data for the year of } 2015 \text { was } \\
\text { collected from International energy agency as } \\
\text { stated in Table A3) }\end{array}$ \\
\hline
\end{tabular}

\section{Textile Production Stage Inventory}

TABle A5. TeXtile Production InVEntory With Dataset

Type of inventory Inventory

Dataset used to model the inventory

\begin{tabular}{|c|c|c|c|}
\hline \multicolumn{4}{|c|}{ Yarn production (spinning) } \\
\hline \multirow[t]{3}{*}{ Input } & & $\begin{array}{l}\text { From raw fibre production (amount calculated based } \\
\text { on the functional unit) }\end{array}$ & \\
\hline & \multirow[t]{2}{*}{ Electric energy } & $\begin{array}{l}\text { Knit yarn: } 1.76 \mathrm{kWh} / \mathrm{kg} \\
\text { woven yarn: } 2.1 \mathrm{kWh} / \mathrm{kg}[\mathrm{A} 5]\end{array}$ & \multirow[t]{2}{*}{$\begin{array}{l}\text { From electricity mix } \\
\text { model }\end{array}$} \\
\hline & & $\begin{array}{l}\text { Woollen yarn: } \\
2.85 \mathrm{kWh} / \mathrm{kg}[\mathrm{A} 6]\end{array}$ & \\
\hline \multirow[t]{4}{*}{ Output } & Yarn & $\begin{array}{l}\text { Calculation based on the functional unit and material } \\
\text { waste. }\end{array}$ & \\
\hline & \multirow[t]{3}{*}{$\begin{array}{l}\text { Wastage (Material } \\
\text { loss during spinning) }\end{array}$} & $\begin{array}{l}\text { Cotton yarn: } \\
\text { Average } 13-30 \% \text { (Average data from industry } \\
\text { source) }\end{array}$ & \multirow{3}{*}{$\begin{array}{l}\text { Waste textile, soiled } \\
\text { (waste treatment) } \\
\{\text { GLO }\} \mid \text { market for } \\
\text { waste textile, soiled } \\
\text { Alloc Def, } U\end{array}$} \\
\hline & & $\begin{array}{l}\text { Manmade yarn: } \\
\text { Average } 4-9 \% \text { (Average data from industry source) }\end{array}$ & \\
\hline & & $\begin{array}{l}\text { Wool yarn: } \\
\text { Average } 10 \%[\mathrm{~A} 7]\end{array}$ & \\
\hline \multicolumn{4}{|c|}{ Fabric production process (Knitting and weaving) } \\
\hline \multirow[t]{4}{*}{ Input } & Yarn & From yarn production process & \\
\hline & \multirow[t]{3}{*}{ Electric energy } & $\begin{array}{l}\text { Knitting process: } \\
0.086 \mathrm{kWh} / \mathrm{kg}[\mathrm{A} 8]\end{array}$ & \multirow[t]{3}{*}{$\begin{array}{l}\text { From electricity mix } \\
\text { model }\end{array}$} \\
\hline & & $\begin{array}{l}\text { Warping and sizing (for weaving process): } 0.0073 \\
\mathrm{kWh} / \mathrm{kg} \text { [A9] }\end{array}$ & \\
\hline & & Weaving process: & \\
\hline
\end{tabular}




\begin{tabular}{|c|c|c|c|}
\hline & & $\begin{array}{l}1.58-2.24 \mathrm{kWh} / \mathrm{kg} \text { (we considered } 1.9 \mathrm{kWh} / \mathrm{kg} \text { ) [A9], } \\
\text { [A10] }\end{array}$ & \\
\hline & $\begin{array}{l}\text { Needle oil during } \\
\text { knitting }\end{array}$ & Amount from reference $[\mathrm{A} 11]$ & $\begin{array}{l}\text { Lubricating oil } \\
\{\text { GLO }\} \mid \text { market for } \mid \\
\text { Alloc Def, } U\end{array}$ \\
\hline & $\begin{array}{l}\text { Yarn sizing } \\
\text { ingredients for } \\
\text { woven fabric }\end{array}$ & Amount from reference [A12] & Ecoinvent v3 dataset \\
\hline \multirow[t]{3}{*}{ Output } & Knit/ woven fabric & $\begin{array}{l}\text { Calculation based on the functional unit and material } \\
\text { waste. }\end{array}$ & \\
\hline & \multirow[t]{2}{*}{$\begin{array}{l}\text { (Wastage) Material } \\
\text { loss }\end{array}$} & $\begin{array}{l}\text { Knitting: } \\
\text { Average } 3 \%[\mathrm{~A} 13]\end{array}$ & \multirow{2}{*}{$\begin{array}{l}\text { Waste textile, soiled } \\
\text { (waste treatment) } \\
\{\text { GLO }\} \mid \text { market for } \\
\text { waste textile, soiled | } \\
\text { Alloc Def, U }\end{array}$} \\
\hline & & $\begin{array}{l}\text { Weaving: } \\
\text { Average } 3.7 \% \text { [A14] }\end{array}$ & \\
\hline \multicolumn{4}{|c|}{ Wet treatment and finishing } \\
\hline \multirow[t]{5}{*}{ Input } & Fabric (knit / weave) & From fabric production process & \\
\hline & $\begin{array}{l}\text { Chemicals and } \\
\text { auxiliaries }\end{array}$ & $\begin{array}{l}\text { Amount of chemicals and auxiliaries were adopted } \\
\text { from reference (large number of chemicals and } \\
\text { auxiliaries were used during wet treatment that are } \\
\text { difficult to tabulated here) [A12]. }\end{array}$ & Ecoinvent v3 dataset \\
\hline & Dyestuffs & $\begin{array}{l}\text { Amount of dyestuffs were adopted from reference } \\
\text { [A12]. }\end{array}$ & $\begin{array}{l}\text { Ecoinvent v3 dataset } \\
\text { (proxy dataset) }\end{array}$ \\
\hline & & & $\begin{array}{l}50 \% \text { Chemicals } \\
\text { organic, at } \\
\text { plant/GLO U + } \\
50 \% \text { Chemicals } \\
\text { inorganic, at } \\
\text { plant/GLO [A6] }\end{array}$ \\
\hline & Water & $\begin{array}{l}\text { Typical ML (textile material and liquor ratio) ratio } \\
\text { was adopted from reference [A12]. }\end{array}$ & $\begin{array}{l}\text { Tap water }\{\mathrm{GLO}\} \mid \text { tap } \\
\text { water production, } \\
\text { seawater reverse } \\
\text { osmosis, conventional } \\
\text { pre-treatment, } \\
\text { baseline module, } \\
\text { single stage } \mid \text { Alloc } \\
\text { Def, U }\end{array}$ \\
\hline \multirow[t]{2}{*}{ Output } & Finished fabric & $\begin{array}{l}\text { Calculation based on the functional unit and material } \\
\text { waste. }\end{array}$ & \\
\hline & $\begin{array}{l}\text { Emissions in } \\
\text { wastewater }\end{array}$ & $\begin{array}{l}\text { Emissions were calculated based on the guideline of } \\
\text { IPCC and OECD [A15], [A16]. Details of the } \\
\text { emissions calculation were mentioned in previous } \\
\text { study [A17]. }\end{array}$ & Ecoinvent v3 dataset \\
\hline
\end{tabular}

Apparel make up process

\begin{tabular}{|c|c|c|c|}
\hline Input & Fabric (knit/ woven) & From fabric production process & \\
\hline & $\begin{array}{l}\text { Electricity (knit } \\
\text { apparel) }\end{array}$ & $2.67 \mathrm{kWh} / \mathrm{kg}[\mathrm{A} 18]$ & $\begin{array}{l}\text { From electricity mix } \\
\text { model }\end{array}$ \\
\hline & $\begin{array}{l}\text { Electricity (woven } \\
\text { apparel) }\end{array}$ & $2.23 \mathrm{kWh} / \mathrm{kg}$ [A18] & \\
\hline & Heat (knit) & $3.6 \mathrm{kWh} / \mathrm{kg}[\mathrm{A} 18]$ & $\begin{array}{l}\text { Heat, central or small- } \\
\text { scale, natural gas, }\end{array}$ \\
\hline & Heat (woven) & $3.6 \mathrm{MJ} / \mathrm{kg}[\mathrm{A} 18]$ & $\begin{array}{l}\text { Jakobsberg }\{\mathrm{GLO}\} \mid \\
\text { market for } \mid \text { Alloc } \\
\text { Def, U }\end{array}$ \\
\hline Output & Finished apparel & $\begin{array}{l}\text { Calculation based on the functional unit and material } \\
\text { waste for different apparel. }\end{array}$ & \\
\hline
\end{tabular}




\begin{tabular}{lll}
\hline Wastage & Calculation based on reference & Waste textile, soiled \\
& Material waste [A19]: & [A20] $\{$ GLO $\} \mid$ market \\
& Shirt $-13 \%$ & for waste textile, \\
& Dress $-18 \%$ & soiled $\mid$ Alloc Def, U \\
& Trouser $-14 \%$ & \\
& Swimwear- $18 \%$ & \\
& Suit $-14 \%$ \\
& Gloves $-18 \%$ & \\
Dressing gown $-15 \%$ & \\
Jacket - $16 \%$ & Under apparel - $16 \%$ & \\
\hline
\end{tabular}

Note: Ecoinvent dataset for chemicals used in wet treatment process did not mention due to the limitation of space.

\section{END OF LIFE INVENTORY}

TABLE A6. END OF LIFE INVENTORY

\begin{tabular}{|c|c|c|c|c|}
\hline & Inventory type & Inventory & Unit & $\begin{array}{l}\text { Dataset used to } \\
\text { model }\end{array}$ \\
\hline \multirow[t]{2}{*}{$\begin{array}{l}\text { Landfill ( } 25 \% \text { of } \\
\text { the disposed textile) }\end{array}$} & Landfill amount & $\begin{array}{l}\text { From use stage ( } 25 \% \text { of } \\
\text { the disposed textile) }\end{array}$ & $\mathrm{kg}$ & $\begin{array}{l}\text { Waste treatment, } \\
\text { textiles, at } \\
\text { landfill/AU U }\end{array}$ \\
\hline & Transportation to landfill & $20 \mathrm{~km}[\mathrm{~A} 21]$ & $\mathrm{kg} \mathrm{km}$ & $\begin{array}{l}\text { Transport, truck, } \\
16 \text { to } 28 \text { t, fleet } \\
\text { average/AU U }\end{array}$ \\
\hline \multirow[t]{2}{*}{$\begin{array}{l}\text { Reuse in Australia } \\
\text { ( } 35 \% \text { of the } \\
\text { disposed textiles) }\end{array}$} & $\begin{array}{l}\text { Electricity use for reuse } \\
\text { (collection, processing, and } \\
\text { distribution of used clothing) }\end{array}$ & $\begin{array}{l}1.7 \mathrm{kWh} / \mathrm{kg} \text { used cloth } \\
\text { (Based on a SATC } \\
\text { (salvation army trading } \\
\text { company report) [A22]. }\end{array}$ & $\mathrm{kWh}$ & $\begin{array}{l}\text { Electricity, } \\
\text { medium voltage } \\
\{\text { AU }\} \mid \text { market for } \\
\mid \text { Alloc Def, } U\end{array}$ \\
\hline & $\begin{array}{l}\text { transportation to local reuse } \\
\text { (Australia) by track }\end{array}$ & $20 \mathrm{~km}[\mathrm{~A} 21]$ & $\mathrm{kg} \mathrm{km}$ & $\begin{array}{l}\text { Transport, truck, } \\
16 \text { to } 28 \text { t, fleet } \\
\text { average/AU U }\end{array}$ \\
\hline \multirow[t]{2}{*}{$\begin{array}{l}\text { Reuse in overseas } \\
\text { ( } 40 \% \text { of the } \\
\text { disposed textiles) }\end{array}$} & $\begin{array}{l}\text { Transportation to overseas } \\
\text { reuse by ship }\end{array}$ & $\begin{array}{l}10000 \mathrm{~km} \text { (average sea } \\
\text { distance to main import } \\
\text { country of used apparel } \\
\text { from Australia [A23] }\end{array}$ & $\mathrm{kg} \mathrm{km}$ & $\begin{array}{l}\text { Transport, } \\
\text { transoceanic } \\
\text { freight ship/OCE } \\
\text { U/AusSD U }\end{array}$ \\
\hline & $\begin{array}{l}\text { Transport for reuse overseas by } \\
\text { truck }\end{array}$ & $20 \mathrm{~km}[\mathrm{~A} 21]$ & $\mathrm{kg} \mathrm{km}$ & $\begin{array}{l}\text { Transport, truck, } \\
16 \text { to } 28 \text { t, fleet } \\
\text { average/AU U }\end{array}$ \\
\hline
\end{tabular}

\section{TRANSPORT AND DISTRIBUTION}

Table A7. Travel Distance for Sea Freight and Air Freight for Transportation of FINISHED APPAREL FROM PRODUCTION COUNTRY TO CONSUME COUNTRY (AUSTRALIA)

\begin{tabular}{lll}
\hline Clothing production country & $\begin{array}{l}\text { Sea distance to Melbourne port } \\
\text { from clothing production country } \\
\text { [A23], nautical miles }\end{array}$ & $\begin{array}{l}\text { Air distance to Melbourne } \\
\text { from clothing production } \\
\text { country [A24], nautical miles }\end{array}$ \\
\hline Bangladesh, Chittagong port & 5337 & 4811.8 \\
China, shanghai port & 5193 & 4975.5 \\
India, Mumbai port & 5558 & 5116.1 \\
Indonesia, Jakarta port & 3385 & 2809.7 \\
Vietnam, Ho Chi Minh & 4364 & 3741.7 \\
Sihanoukville port, Cambodia & 5032 & 3773.0 \\
\hline Average distance, nautical miles & 4811.5 & 4204.6 \\
\hline
\end{tabular}




\section{Detergent Production Process Model}

Detergents are available in liquid or powder form. The composition of chemicals and ingredients differed according to the form. For simplification for this study we can assume $100 \%$ powder detergent due to the lack of data. Inventory data for powder washing detergent have been collected from the previous life cycle assessment study for laundry detergents of the Procter \& Gamble Company (P \& G) as shown in Table A8. We calculated inventory for $1 \mathrm{~kg}$ detergent production.

TABLE A8. INVENTORY FOR DETERGENT PRODUCTION [A25]

\begin{tabular}{|c|c|c|}
\hline Detergent ingredients & Amount & Database used \\
\hline \multicolumn{3}{|l|}{ INPUT } \\
\hline AE11-PO & $2 \%$ & $\begin{array}{l}\text { Ethoxylated alcohol (AE11) }\{\text { GLO }\} \mid \text { market for } \mid \\
\text { Alloc Def, U }\end{array}$ \\
\hline AE7-pc & $4 \%$ & $\begin{array}{l}\text { Ethoxylated alcohol (AE7) }\{\text { GLO }\} \mid \text { market for } \mid \\
\text { Alloc Def, } U\end{array}$ \\
\hline LAS-pc & $7.8 \%$ & $\begin{array}{l}\text { Ethoxylated alcohols, unspecified, at plant/RER } \\
\text { U/AusSD U }\end{array}$ \\
\hline Citric acid & $5.2 \%$ & Citric acid $\{\mathrm{GLO}\} \mid$ market for $\mid$ Alloc Def, $\mathrm{U}$ \\
\hline Na-Silicate powder & $3 \%$ & $\begin{array}{l}\text { Layered sodium silicate, SKS- } 6 \text {, powder }\{\text { GLO }\} \mid \\
\text { market for } \mid \text { Alloc Def, } U\end{array}$ \\
\hline Zeolite & $20.1 \%$ & Zeolite, powder $\{\mathrm{GLO}\} \mid$ market for $\mid$ Alloc Def, $U$ \\
\hline Sodium carbonate & $17 \%$ & $\begin{array}{l}\text { Sodium carbonate from ammonium chloride } \\
\text { production, at plant/GLO U/AusSD U }\end{array}$ \\
\hline Perborate monohydrate & $8.7 \%$ & $\begin{array}{l}\text { Sodium perborate, tetrahydrate, powder }\{\mathrm{GLO}\} \mid \\
\text { market for } \mid \text { Alloc Def, } U\end{array}$ \\
\hline Perborate tetrahydrate & $11.5 \%$ & $\begin{array}{l}\text { Sodium perborate, tetrahydrate, powder }\{\mathrm{GLO}\} \mid \\
\text { market for } \mid \text { Alloc Def, } U\end{array}$ \\
\hline Antifoam S1.2-3522 & $0.5 \%$ & \\
\hline FWA DAS-1 & $0.2 \%$ & \\
\hline Polyacrylate & $4 \%$ & \\
\hline Protease & $1.4 \%$ & \\
\hline Sodium sulfate & $0.4 \%$ & $\begin{array}{l}\text { Sodium sulfate, anhydrite }\{\mathrm{RER}\} \mid \text { market for } \mid \\
\text { Alloc Def, } U\end{array}$ \\
\hline Water & $14.2 \%$ & $\begin{array}{l}\text { Water, completely softened, from decarbonised } \\
\text { water, at user }\{\mathrm{GLO}\} \mid \text { market for } \mid \text { Alloc Def, } U\end{array}$ \\
\hline Energy & $\begin{array}{l}0.25 \mathrm{GJ} / 1000 \\
\text { wash }(100 \mathrm{~kg})\end{array}$ & $\begin{array}{l}\text { Electricity, medium voltage }\{A U\} \mid \text { market for } \mid \\
\text { Alloc Def, } U\end{array}$ \\
\hline \multicolumn{3}{|l|}{ OUTPUT } \\
\hline Detergent & $1 \mathrm{~kg}$ & \\
\hline Emissions to air $\mathrm{CO}_{2}$ & $\begin{array}{l}13.3 \mathrm{~kg} / 1000 \\
\text { wash, } 100 \mathrm{~kg}\end{array}$ & Carbon dioxide \\
\hline Emissions to air $\mathrm{CO}$ & $\begin{array}{l}6.0 \mathrm{~g} / 1000 \\
\text { wash, } 100 \mathrm{~kg}\end{array}$ & Carbon monoxide \\
\hline Emissions to air SOx & $\begin{array}{l}69.6 \mathrm{~g} / 000 \text { wash } \\
(100 \mathrm{~kg})\end{array}$ & Sulfur dioxide \\
\hline
\end{tabular}




\begin{tabular}{lll}
\hline Emissions to air NOx & $\begin{array}{l}32.9 \mathrm{~g} / 1000 \\
\text { wash }(100 \mathrm{~kg})\end{array}$ & Nitrogen oxides \\
& $109 \mathrm{~g} / 1000$ \\
& wash $(100 \mathrm{~kg})$ & \\
Emissions to air CxHy & $17.6 \mathrm{~g} / 1000$ & \\
& wash $(100 \mathrm{~kg})$ & \\
Emissions to air & $\begin{array}{l}4.9 \mathrm{~g} / 1000 \mathrm{wash} \\
\text { Particles/dust }\end{array}$ & BOD5, Biological Oxygen Demand \\
Emissions to water BOD & $(100 \mathrm{~kg})$ & \\
& $10.1 \mathrm{~g} / 1000$ & COD, Chemical Oxygen Demand \\
Emissions to water COD & wash $(100 \mathrm{~kg})$ & \\
& & \\
\hline
\end{tabular}

\section{Data Quality ASSESSMent}

Table A9. Data Quality ASSESSMENT

\begin{tabular}{|c|c|c|c|c|c|c|c|}
\hline & 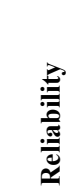 & נ丶 & 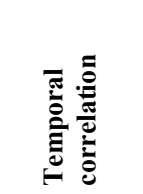 & 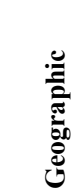 & 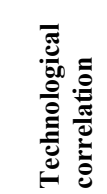 & 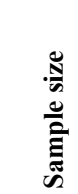 & 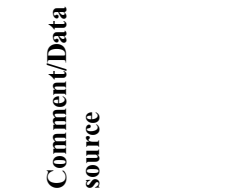 \\
\hline 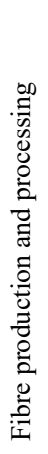 & $m$ & - & 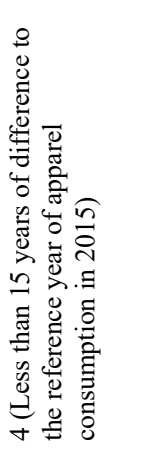 & $m$ & $N$ & $\overleftrightarrow{z}$ & 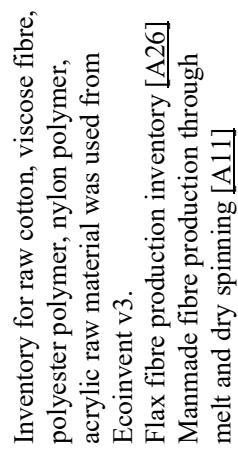 \\
\hline . & $m$ & $m$ & 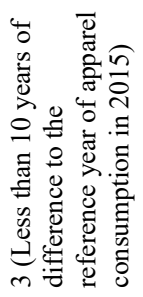 & $m$ & $\mathrm{~N}$ & $\overleftrightarrow{z}$ & 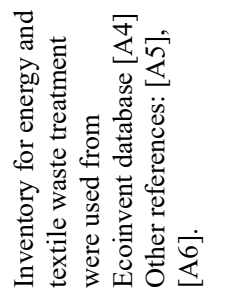 \\
\hline
\end{tabular}




\begin{tabular}{|c|c|c|c|c|c|c|c|}
\hline 蓄 & $m$ & $m$ & 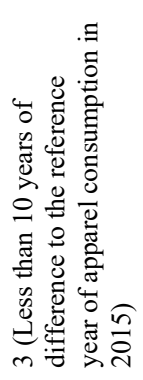 & $m$ & $N$ & $\overleftrightarrow{z}$ & 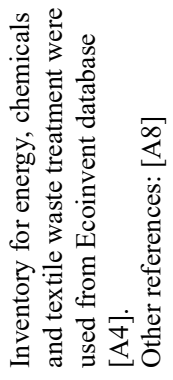 \\
\hline$\frac{0.00}{\underbrace{0}_{0}}$ & $m$ & $N$ & 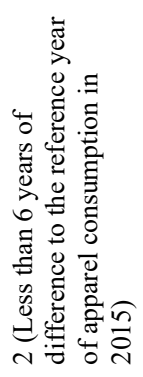 & $m$ & $N$ & & 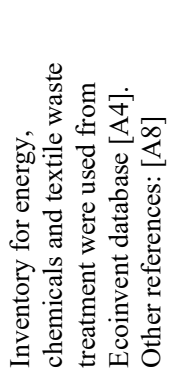 \\
\hline 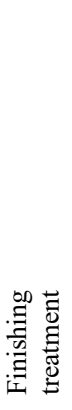 & $m$ & $N$ & 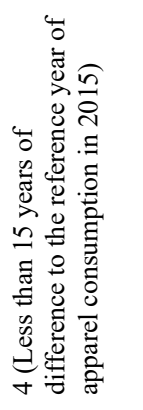 & $m$ & $N$ & $\overleftrightarrow{z}$ & 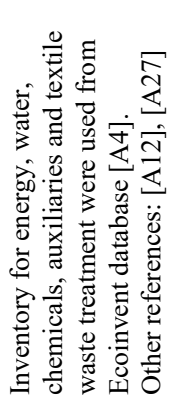 \\
\hline 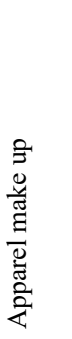 & $m$ & $N$ & 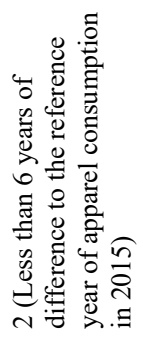 & $n$ & $N$ & $\overleftrightarrow{\mathrm{z}}$ & 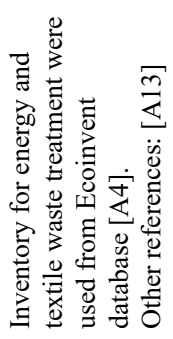 \\
\hline
\end{tabular}




\begin{tabular}{|c|c|c|c|c|c|c|c|}
\hline 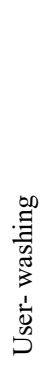 & $N$ & $N$ & 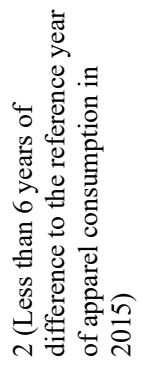 & - & - & $\overleftrightarrow{z}$ & 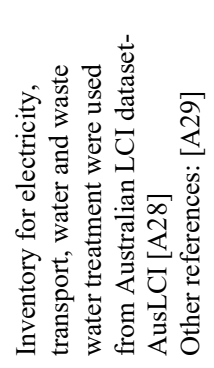 \\
\hline 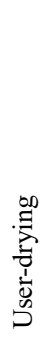 & $N$ & $N$ & 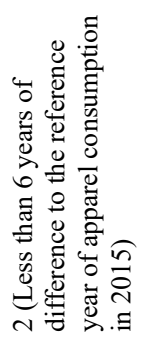 & - & - & $\overleftrightarrow{z}$ & 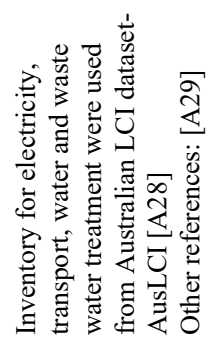 \\
\hline 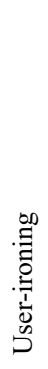 & $N$ & N & 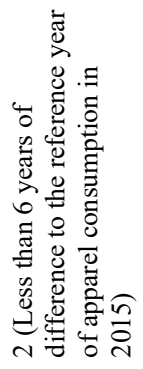 & - & - & $\overleftrightarrow{z}$ & 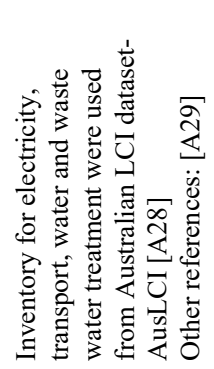 \\
\hline 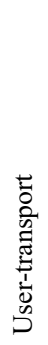 & $N$ & $N$ & 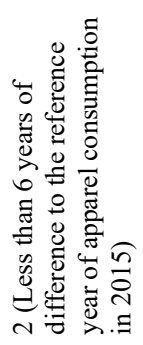 & - & - & 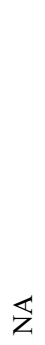 & 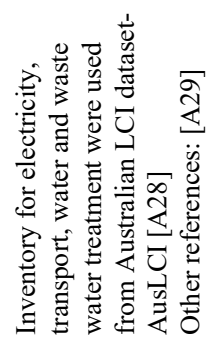 \\
\hline
\end{tabular}




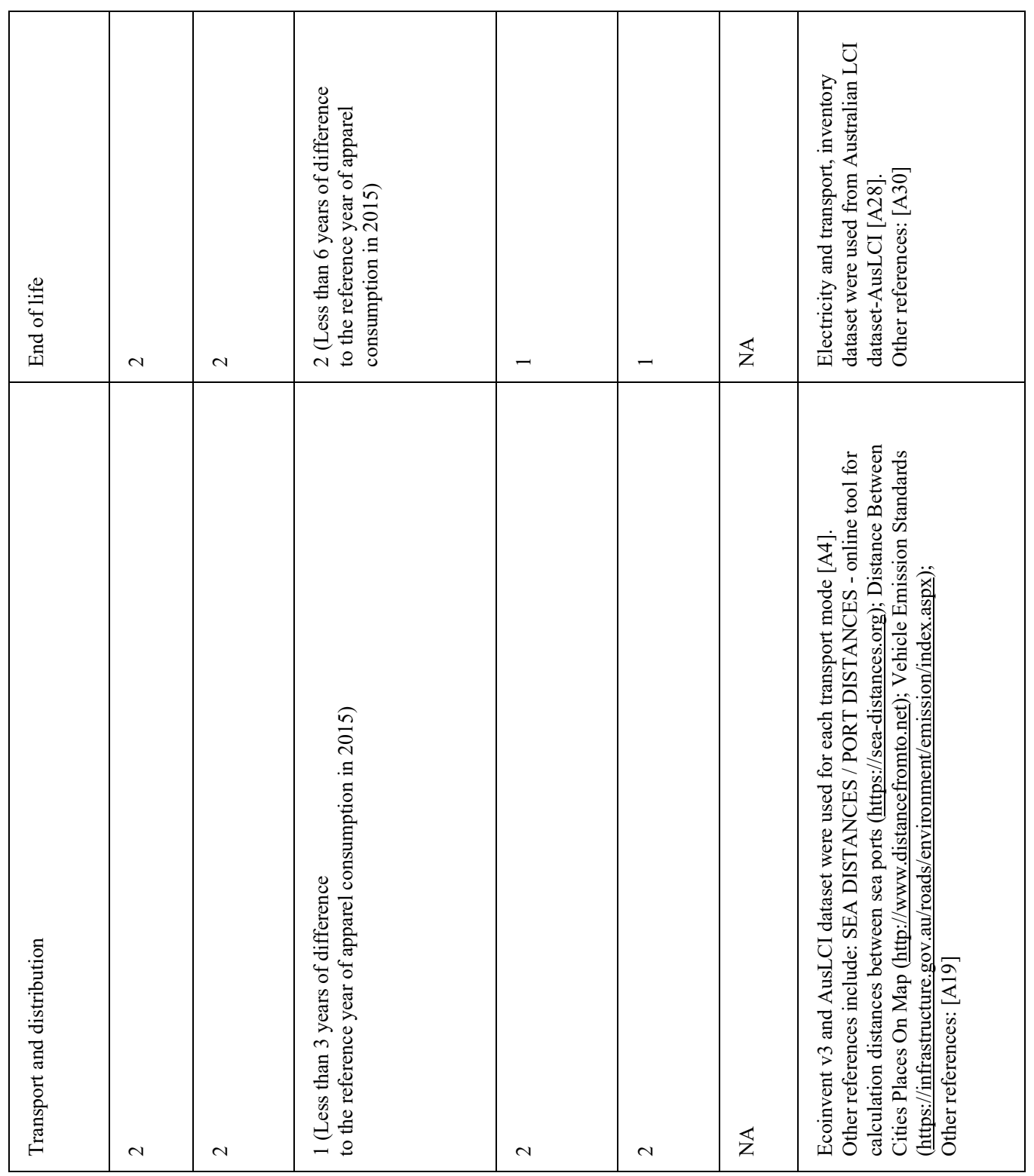

TABLE A10. APPENDiX REFERENCES

\begin{tabular}{|c|l|}
\hline [A1] & $\begin{array}{l}\text { United Nations Department of Economic and Social Affairs. UN Comtrade Database. [Online]. } \\
\text { [Accessed: 13.06.2019]. Available: https://comtrade.un.org/data/ }\end{array}$ \\
\hline [A2] & $\begin{array}{l}\text { The International Energy Agency. Total primary energy supply (TPES) by source. 2020. [Online]. } \\
\text { [Accessed: 02.02.2020]. Available: https://www.iea.org/countries/bangladesh }\end{array}$ \\
\hline [A3] & $\begin{array}{l}\text { Re:newcell. About Re:newcell. 2015. [Online]. [Accessed 03.02.2019]. Available: } \\
\text { http://renewcell.se/about/ }\end{array}$ \\
\hline [A4] & $\begin{array}{l}\text { The Ecoinvent v3 Database. The Ecoinvent Database v3. In: The Swiss Centre for Life Cycle Inventories. } \\
\text { 2013. [Online]. [Accessed: 12.03.2019]. Available: http://www.ecoinvent.org/database/database.html }\end{array}$ \\
\hline
\end{tabular}




\begin{tabular}{|c|c|}
\hline [A5] & $\begin{array}{l}\text { Koç E., Kaplan E. An investigation on energy consumption i yarn production with special reference to ring } \\
\text { spinning. Fibres Text East Eur 2007:15(4):18-24. }\end{array}$ \\
\hline [A6] & $\begin{array}{l}\text { Cardoso AAM. Life Cycle Assessment of Two Textile Products Wool and Cotton. Faculty of Engineering. } \\
\text { MASTER ON ENVIRONMENTAL ENGINEERING. Porto University; 2013. [Online]. [Accessed: } \\
\text { 05.03.2019]. https://repositorio-aberto.up.pt/bitstream/10216/85778/2/26984.pdf }\end{array}$ \\
\hline [A7] & $\begin{array}{l}\text { Strand J. Environmental Impact of the Swedish Textile Consumption: A General LCA Study. Department } \\
\text { of Energy and Technology. Swedish University of Agricultural Sciences. 2015. [Online]. [Accessed: } \\
\text { 15.03.2019]. Available: http://urn.kb.se/resolve?urn=urn:nbn:se:uu:diva-256654 }\end{array}$ \\
\hline [A8] & $\begin{array}{l}\text { Cotton Incorporated. The life cycle inventory and life cycle assessment of cotton fiber and fabric-full } \\
\text { report. [Online]. [Accessed: 10.02.2019]. Available: https://cottoncultivated.cottoninc.com/wp- } \\
\text { content/uploads/2015/06/2012-LCA-Full-Report.pdf }\end{array}$ \\
\hline [A9] & $\begin{array}{l}\text { Palamutcu S. Electric energy consumption in the cotton textile processing stages. Energy 2010:35(7):2945- } \\
\text { 2952. https://doi.org/10.1016/j.energy.2010.03.029 }\end{array}$ \\
\hline [A10] & $\begin{array}{l}\text { Koç E., Çinçik E. Analysis of energy consumption in woven fabric production. Fibres Text East Eur } \\
\text { 2010:18(2):79. }\end{array}$ \\
\hline [A11] & $\begin{array}{l}\text { Laursen S. E., Hansen J., Bagh J., Jensen O., Werther I. Environmental Assessment of Textiles. Life } \\
\text { Cycle Screening of Textiles Containing Cotton, Wool, Viscose, Polyester or Acrylic Fibres. } \\
\text { MILJOPROJEKT 1997:369. https://doi.org/10.13140/RG.2.1.2584.1124 }\end{array}$ \\
\hline [A12] & $\begin{array}{l}\text { Schönberger H., Schäfer T. Best Available Techniques in Textile Industry. Berlin: Federal Environmental } \\
\text { Agency, 2003. }\end{array}$ \\
\hline [A13] & $\begin{array}{l}\text { Baydar G., Ciliz N., Mammadov A. Life cycle assessment of cotton textile products in Turkey. Resources, } \\
\text { Conservation and Recycling 2015:104:213-223. https://doi.org/10.1016/j.resconrec.2015.08.007 }\end{array}$ \\
\hline [A14] & $\begin{array}{l}\text { Wang C. et al. Carbon footprint of textile throughout its life cycle: a case study of Chinese cotton shirts. } \\
\text { Journal of Cleaner Production 2015:108:464 475. https://doi.org/10.1016/j.jclepro.2015.05.127 }\end{array}$ \\
\hline [A15] & $\begin{array}{l}\text { Intergovernmental Panel on Climate Change. IPCC guidelines for national greenhouse gas inventories. } \\
\text { Institute for Global Environmental Strategies, Hayama, Japan 2006:2:48-56. [Online]. [Accessed: } \\
\text { 15.04.2019]. Available: https://www.ipcc-nggip.iges.or.jp/public/2006gl/. }\end{array}$ \\
\hline [A16] & $\begin{array}{l}\text { The Organisation for Economic Co-operation and Development. OECD, Emission scenario document on } \\
\text { textile industry. OECD Series on Emission Scenario Documents, 2004. [Online]. [Accessed: 10.03.2019]. } \\
\text { Available: } \\
\text { http://www.oecd.org/officialdocuments/publicdisplaydocumentpdf/?cote=ENV/JM/MONO(2004)12\&doc } \\
\text { language=en. }\end{array}$ \\
\hline [A17] & $\begin{array}{l}\text { Moazzem S., Daver F., Crossin E., Wang L. Assessing environmental impact of textile supply chain using } \\
\text { life cycle assessment methodology. The Journal of the Textile Institute 2018:109(12):1574-1585. } \\
\text { https://doi.org/10.1080/00405000.2018.1434113 }\end{array}$ \\
\hline [A18] & $\begin{array}{l}\text { Roos S., Sandin G., Zamani B., Peters G. Environmental assessment of Swedish fashion consumption, Five } \\
\text { garments-sustainable futures. Mistra Future Fashion. 2015. [Online]. [Accessed: 12.03.2019]. Available: } \\
\text { http://mistrafuturefashion.com/wp-content/uploads/2015/06/Environmental-assessment-of-Swedish- } \\
\text { fashion-consumption-LCA.pdf. }\end{array}$ \\
\hline [A19] & $\begin{array}{l}\text { Beton A. et al. Environmental Improvement Potential of Textiles (IMPRO-Textiles). European } \\
\text { Commission. 2014. https://doi.org/10.2791/52624 }\end{array}$ \\
\hline [A20] & $\begin{array}{l}\text { Henze M., Comeau Y. Wastewater characterization. In: Henze M., van Loosdrecht M. C. M., Ekama G. A., } \\
\text { Brdjanovic D., (eds). Biological Wastewater Treatment: Principles, Modelling and Design. London: IWA } \\
\text { Publishing, 2008. }\end{array}$ \\
\hline [A21] & $\begin{array}{l}\text { NSW DECCW. The extended benefits of recycling - life cycle assessment: Appendix } 6 \text { - Plastics PET, } \\
\text { HDPE, PVC, mixed plastics and rubber tyres. In: The Department of Environment CCaWN, 2010. [Online]. } \\
\text { [Accessed: 10.12.2019]. Available: https://www.epa.nsw.gov.au/-/media/epa/corporate- } \\
\text { site/resources/warrlocal/100058-plastics.pdf }\end{array}$ \\
\hline [A22] & $\begin{array}{l}\text { Collins M., Aumônier S. Streamlined life cycle assessment of two Marks \& Spencer plc apparel products. } \\
\text { Environmental Resources Management. Oxford, } 2002 .\end{array}$ \\
\hline [A23] & $\begin{array}{l}\text { Sea-Distance.org. SEA DISTANCES / PORT DISTANCES - online tool for calculation distances between } \\
\text { sea ports. [Online]. [Accessed: } 8.12 .2016 \text { ]. Available: https://sea-distances.org }\end{array}$ \\
\hline
\end{tabular}




\begin{tabular}{|c|l|l|}
\hline [A24] & $\begin{array}{l}\text { Distance from to. Distance Between Cities Places On Map. [Online]. [Accessed: 12 December 2016]. } \\
\text { Available: http://www.distancefromto.net }\end{array}$ \\
\hline [A25] & $\begin{array}{l}\text { Saouter E., Hoof G. V. A database for the life-cycle assessment of Procter \& Gamble laundry detergents. } \\
\text { The International Journal of Life Cycle Assessment 2002:7(2):103-114. } \\
\text { https://doi.org/10.1007/BF02978854 }\end{array}$ \\
\hline [A26] & $\begin{array}{l}\text { Dissanayake N., Summerscales J., Grove S., Singh M. Quantitative life cycle analysis for flax fibers. } \\
\text { Proceedings of the 17th International Conference for Composite Materials, 2009. }\end{array}$ \\
\hline [A27] & $\begin{array}{l}\text { European Commission. Integrated Pollution Prevention and Control (IPPC), Reference Document on Best } \\
\text { Available Techniques for the Textiles Industry. European Commission. 2003. }\end{array}$ \\
\hline [A28] & $\begin{array}{l}\text { AusLCI. The Australian National Life Cycle Inventory Database (AusLCI). In: The Australian Life Cycle } \\
\text { Assessment Society (ALCAS). 2015. [Online]. [Accessed: 15.03.2019]. Available: http://auslci.com.au/ }\end{array}$ \\
\hline [A29] & $\begin{array}{l}\text { Grace P., Gane M., Garcia F. Life Cycle Assessment of a 100 \% Australian Cotton T-shirt. Institute for } \\
\text { Sustainable Resources, Queensland University of Technology, Brisbane QLD, 2009. }\end{array}$ \\
\hline [A30] & $\begin{array}{l}\text { Caulfield K. Sources of Textile Waste in Australia. 2009. [Online]. [Accessed: 15.03.2019]. Available: } \\
\text { http://www.nacro.org.au/wp-content/uploads/2013/04/TEXTILE-WASTE-PAPER-March-2009-final.pdf }\end{array}$ \\
\hline
\end{tabular}

